\title{
The onset of the palaeoanthropocene in Iceland: changes to complex natural systems
}

\author{
Richard Streeter, ${ }^{1}$ Andrew J Dugmore, ${ }^{2}$ Ian T Lawson, ${ }^{1}$ Egill Erlendsson ${ }^{3}$ and Kevin J \\ Edwards 4
}

1Department of Geography and Sustainable Development, University of St Andrews, UK 2Department of Geography and the Lived Environment, University of Edinburgh, UK ${ }^{3}$ Department of Geography and Tourism, University of Iceland, Iceland 4Departments of Geography \& Environment and Archaeology, University of Aberdeen, UK

\section{Corresponding author:}

Richard Streeter, Department of Geography and Sustainable Development, University of St Andrews, Irvine Building, North Street, St Andrews, Fife, KY16 9AL, UK.

Email: rts3@st-andrews.ac.uk

\begin{abstract}
Pre-industrial human impacts on the past environment are apparent in different proxy records at different times in different places. Recognising environmentallytransformative human impacts in palaeoenvironmental archives, as opposed to natural variability, is a key challenge in understanding the nature of the transition to the Earth's current 'Anthropocene' condition. Here we consider the palaeoenvironmental record for Iceland over the past $2.5 \mathrm{ka}$, both before and after the late-9th century human settlement (landnám). The Scandinavian colonization of the island was essentially abrupt, involving thousands of people over a short period. The colonization triggered extensive changes in Icelandic ecosystems and landscapes. A volcanic ash known as the Landnám
\end{abstract}


tephra was deposited over most of Iceland immediately before the settlement began.

The Landnám tephra layer thus provides a uniquely precise litho-chrono-stratigraphic marker of colonization. We utilise this marker horizon as an independent definition of the effective onset of the local palaeoanthropocene (which is conceptually related to, but distinct from, the global Anthropocene). This allows us to evaluate proxy records for human impact on the Icelandic environment and to assess how and when they show transformative impact. Based on this analysis, we consider the implications for understanding and defining the Anthropocene in those areas of the Earth where such a clear independent marker of the onset of significant human impacts is lacking.

\section{Keywords}

tephra; erosion; landnám; Betula; pollen analysis; soil erosion; colonization 


\section{Introduction}

In this article we evaluate the history of environmental change in Iceland over the past 2.5 ka in order to better comprehend how pre-industrial human impacts on the Earth system are translated into patterns in the proxy environmental record, and in particular to understand how readily a distinct regional 'Anthropocene' may be defined in proxy records.

Following the introduction of the term by Crutzen (2002), debates about the Anthropocene have largely focused on the search for an unambiguous and readily identifiable boundary level for the start date of 'significant' human impacts on the Earth system. While there is an emerging consensus that the beginning of the Anthropocene should be defined at some point since the invention of the steam engine - for example, during the rapid industrialisation and start of the increase in atmospheric $\mathrm{CO}_{2}$ levels of the late $18^{\text {th }}$ century (Zalasiewicz et al., 2011), or the start of the 'great acceleration' of the mid-20th century (Zalasiewicz et al., 2010; Steffan et al., 2015; Zalasiewicz et al., in press)- there are also arguments for pushing the onset further back in time (Ruddiman, 2003; Rick et al. 2013; Ruddiman et al., 2015), or even for merging the Holocene with the Anthropocene (Smith and Zeder, 2013) in recognition of the fact that ecosystems were often extensively modified by pre-industrial societies (Braje and Erlandson, 2013; Rick et al., 2013). Others have concluded that the diachronous nature of human impact on the environment will make a single start date unworkable (Gale and Hoare, 2012; Edgeworth et al., 2015) and that the standard criteria used by geologists to define a new 'golden spike' are unlikely to be met by any of the proposed Anthropocene sections (Zalasiewicz et al., 2011), at least not with useful chronological resolution. Foley et al. (2013) attempted to resolve this argument by proposing that the 'Anthropocene' could be used strictly as a label for the period since AD 1780, and that the 
'palaeoanthropocene' could be used to designate a more weakly defined, transitional period of substantial human impact, which would not necessarily be synchronous everywhere. While this term is clearly related to the concept of the Anthropocene, it is distinct. The emerging consensus for the start date of the Anthropocene is either the start of the industrial revolution or in the $20^{\text {th }}$ century (Zalasiewicz et al., 2015; Lewis and Maslin, 2015). As the focus of this paper is on pre-industrial human impacts we use the more appropriate term of palaeoanthropocene throughout.

The new concept of the palaeoanthropocene therefore places the emphasis on understanding the history of human-environment interactions on a region-by-region basis (Foley et al., 2013). With the possible exception of the early modification of global atmospheric chemistry by rice farming and deforestation (Ruddiman 2003), the timing of the onset of 'substantial' human impact necessarily varies from place to place, following the dispersal of humans and their technologies around the globe. Furthermore, the onset is often temporally diffuse, in the sense that the first settlers often have a very minor impact, but the human impact both intensifies and becomes more spatially extensive over time as more settlers arrive and new technologies are adopted. There is therefore a special value in case studies where the onset of human impact in a region is comparatively abrupt, far-reaching in its environmental consequences, and well-bounded in space and time. Islands are particularly useful as bounded 'natural laboratories' (Edwards and Bird, 2007; Rick et al., 2013). Among islands, Iceland has two significant advantages for this line of research: 1) human settlement came relatively late, which means that the palaeoenvironmental archive remains extensive and little-altered, and is supplemented by a great deal of historical documentation; and 2) human arrival can be clearly and unambiguously dated by the widespread occurrence of a volcanic ash (tephra) layer, the 'Landnám’ (Old Norse: landtaking) tephra, which was fortuitously deposited across almost the whole island just 
before the arrival of the first major wave of Scandinavian settlers in the late ninth century (Vésteinsson et al., 2006) .

Environmental changes in Iceland resulting from human settlement are widely acknowledged to have been extensive in the sense that they eventually affected almost the whole island to a substantial degree (Dugmore et al., 2000; Arnalds et al., 2001; Lawson et al., 2007; Erlendsson et al., 2009), but they are also spatially complex in that the pattern of change through time varies from site to site (Dugmore et al., 2005; Streeter and Dugmore, 2014).

Our principal aim in this article is to assess the way in which the onset of the local palaeoanthropocene is represented in palaeoenvironmental archives. We assume that the Landnám tephra layer is an unambiguous chrono-litho-stratigraphic marker for the onset of human impact, at least within a decade or so. We compile proxy records of two key environmental parameters, soil erosion and forest cover change, and perform a quantitative analysis in order to assess how the local onset of the palaeoanthropocene would be interpreted in the absence of independent information (written records, extensive archaeological data, and the Landnám tephra layer) about its timing, spatial extent, and other properties. This provides a new insight into the degree to which the nature and timing of pre-industrial human impacts are likely to be visible in palaeoecological records more generally. A second aim is to investigate how initially small-scale changes coalesced to alter the environment substantially across an entire island.

\section{Methods and rationale}

The settlement of Iceland was a rapid event, probably involving 24,000 incomers settling much of the vegetated area (which forms a fringe around a central sub-arctic 
desert) within 20 years (Edwards, 2012; Vésteinsson and McGovern, 2012). They brought with them a complete 'terraforming package' of domesticated animals and plants, iron tools and other technologies, and established practices for exploiting environmental resources that had been developed mainly in Scandinavia. It appears therefore that substantial human impacts on the environment would have begun within a few decades of the deposition of the Landnám tephra layer, though not necessarily everywhere in Iceland.

In order to determine the nature of changes associated with the arrival of people, we analyse two environmental indicators which have been used to reconstruct past environmental changes attributed primarily to human impact. These indicators are 1) rates of sediment accumulation in aeolian soils, which is interpreted as a proxy for soil erosion in the surrounding area (Thórarinsson, 1961; Dugmore and Buckland, 1991; Gísladóttir et al., 2010; Streeter and Dugmore, 2014); and 2) the percentage of Betula (birch) pollen in peat and lake (and marine) sediments, which can be interpreted as a proxy for woodland cover (Lawson et al., 2007). These proxies capture two important trends of environmental change in Iceland over the past 1200 years; increasing rates of soil erosion (Arnalds et al., 2001) and declining woodland cover (Hallsdóttir, 1996).

Tephrochronology at its best can provide distinct chrono-litho-stratigraphic marker horizons that precisely connect environmental archives of terrestrial, lacustrine, marine and cryospheric environments (Lowe, 2011). Tephrochronology was developed in Iceland by Thórarinsson (1944) and has been widely applied in subsequent palaeoecological research. One of the tephras he identified, the Landnám tephra layer, provides a useful marker for the regional onset of human modification of the environment (the landnám period; Vésteinsson and McGovern, 2012). The Landnám tephra has been identified in the Greenland Ice cores, allowing it to be dated precisely by annual layer counting to $871 \pm 2 \mathrm{AD}$ (Grönvold et al., 1995) or $877 \pm 4 \mathrm{AD}$ ( Zielinski et 
al., 1997). The Landnám tephra can be readily distinguished from other tephra layers on the basis of the combined indicators of geochemistry and crystal content, and it is found in soils, peats and lake sediments across most of Iceland (Grönvold et al., 1995; Larsen et al., 1999) (Figure 1).

All analysis was carried out in R 3.0.3 (R core team, 2013) and all dates are given in calendar years $\mathrm{AD}$ or $\mathrm{BC}$.

\section{Sediment accumulation rates}

Changes in SeAR in terrestrial soil sections reflect both local and regional sediment supply and therefore inferred rates of local and regional erosion (Dugmore and Erskine, 1994). Changing rates of soil erosion have also been inferred from lacustrine and marine records and these generally show more limited change over the settlement period (Andrews et al., 2001; Larsen et al., 2012). However, these records probably underrepresent variations in local sediment supply, which may be significant and capable of responding rapidly to human pressures. Local sources of sediment are important and because of the strong spatial patterning inherent in Icelandic soil erosion, it seems likely that significant, widely dispersed local soil erosion frequently occurs without a concurrent signal in aggregate off-site records, as are to be found in lacustrine or marine contexts.

Stratigraphic sections from published and unpublished sources were collated. In total there are SeAR records from 36 locations in Iceland (Figure 1 and Table 1). To best reflect local environmental changes in areas where people lived, we selected only terrestrial sections from sites at low altitude $(<450 \mathrm{~m}$; there are very few permanent settlements higher than this in Iceland). SeARs were calculated by measuring accumulated sediment, excluding discrete tephra layers, between marker tephras of 
known age, and converting to a rate of accumulation in mm/yr (following e.g. Dugmore and Buckland, 1991). Where the SeARs had been published, these values were used; otherwise they were calculated from accumulation totals measured from published section drawings. For three sites the published SeARs were a mean value from multiple soil sections; this is indicated in Table 1. Most post-settlement (after $c$. AD 870) Icelandic tephras are dated from surviving written sources dating from the $12^{\text {th }}$ century, although they do refer to earlier events. The earliest post-settlement tephras (including the Landnám tephra itself) are, strictly speaking, from a pre-literate period and so are dated using other techniques such as ice core layer counting. Pre-settlement (before $c$. AD 870) most tephras are dated by radiocarbon analysis of associated organic material. The tephra horizons used in this study are listed in Table 2. For unpublished sections recorded by the authors, tephra layers were identified on the basis of stratigraphy, morphology, grain size and selected geochemical analysis.

SeAR can tend to increase through time in sections in particular geomorphic settings such as the edge of soil erosion fronts (rofabards; Arnalds, 2000) and next to actively eroding slopes (Thórarinsson, 1961; Dugmore et al., 2009). In addition, the likely impact of mechanized farming practices from the early $20^{\text {th }}$ century could be expected to increase the SeAR (Karlsson, 2000). For these reasons, in sections where there was a $20^{\text {th }}$ century tephra (frequently Katla 1918), SeARs above this layer were excluded from the analysis. All of the sections used here extended downwards to at least one dated tephra layer prior to the Landnám tephra. Selected datasets used in this analysis are plotted in Figure 2 and all of the data points are plotted against time in Figure 4a.

The SeAR values were rescaled so that they ranged from - 1 to 1 in each section in order that trends from sections in different geomorphic and topographic situations could be compared and that the higher SeARs typical of southern Iceland did not obscure observed changes in North Iceland. 
The resulting irregular time series were converted to regular series by calculating the weighted average of SeARs within 100-year windows (Figure 4b and c).

\section{Vegetation Change}

Whereas changes in forest cover in most parts of the world would involve many tree species, in Iceland the only native forest-forming taxon is the downy birch, Betula pubescens. Rowan (Sorbus aucuparia) occurs as an accessory arboreal taxon, but being insect-pollinated it is a rare component of pollen records. This means that the Betula pollen curve in pollen records can be (and has been) interpreted as a proxy for the changing abundance of woodland, albeit with caveats. One important issue is that another species of birch, the dwarf birch, Betula nana, also occurs in Iceland. The pollen of the two species (and their frequent hybrid intermediates: Karlsdóttir et al., 2012) can be separated on the basis of grain size, although such grain size distributions overlap slightly (e.g. Mäkelä, 1996; Caseldine, 2001; Karlsdóttir et al., 2007). Many older records do not routinely separate the two morphotypes, and hence the Betula curve typically includes a proportion of B. nana. Subsequent work has shown that pollen attributable to B. nana is typically less abundant in Icelandic subfossil pollen spectra than pollen attributable to B. pubescens, so it is reasonable to assume, in most cases, that an undifferentiated curve for Betula pollen principally represents the woodland-forming species.

A second important issue is the taphonomic one of reworked pollen within the environment. This particularly applies to lake records, which can receive reworked pollen from old soils during periods of soil erosion. In some cases it is possible tentatively to discriminate between 'fresh' and 'reworked' pollen, because the latter is often visibly damaged. Where this has been undertaken, the post-landnám birch curve 
has been shown sometimes (Gathorne-Hardy et al., 2009), but not always (Hallsdóttir, 1995; Lawson et al., 2007), to be increasingly dominated by reworked pollen.

Time series of Betula pollen proportions in peat, lake sediment and (in one case) marine sediment sequences were compiled using data available through the European Pollen Database (EPD 2014), datasets supplied by the original analysts, or by digitizing published pollen diagrams. In total, 48 datasets were considered. Records from two offshore islands, Heimaey (Hallsdóttir 1984) and Papey (Buckland et al. 1995; Edwards et al., 2004), were excluded because Betula pollen is never present in them in any abundance, meaning that they would not be capable of recording a deforestation event. A further 21 datasets were excluded because they did not extend sufficiently far (at least 500 years) before or after the Landnám tephra to yield a useful record of change across the inferred settlement period. Twenty-five datasets were consequently included in our analysis.

The datasets recorded Betula pollen abundance in many different ways and some recalculations were necessary in order to yield comparable records. In many cases the original authors did not separate B. pubescens and B. nana. For this analysis, where Betula species were originally separated, they have been combined to give a comparable 'Betula (undifferentiated)' dataset. In the few cases where "fresh" pollen grains were separated from "reworked", the counts of "fresh" grains were used in our analysis.

In the original publications, the basis for calculation of Betula proportions varies from one site to another. The main source of variation is the inclusion at some sites of Cyperaceae in the sum. In mires, large variations in Cyperaceae pollen influx, probably related to small-scale fluctuations in the local abundance of Eriophorum and other species, can occur. In these cases, most authors argue that excluding Cyperaceae from the sum gives a better impression of temporal changes in tree birch populations in the 
landscape, although this might include tree (and dwarf) birch growing on the mire itself, as well as on the surrounding mineral soils. For this analysis, the Cyperaceae were excluded from the sum and Betula proportions recalculated if necessary, in order to allow a like-for-like comparison. As a consequence, the sum of grains on which the percentage calculations are based may now be below the conventional acceptable minimum of 300 in some cases (although the necessary information to make a judgment about this is rarely available in the literature). This would not affect the central estimate of birch percentage in a given sample, but may slightly increase the uncertainty in that estimate.

For some sequences the original published age model has been used. For most older datasets it was necessary to recalculate an age model owing to improvements in the dating of tephra layers and in the calibration of radiocarbon dates. Radiocarbon dates were recalibrated using the IntCal13 curve. Age models were generated using (for simplicity and consistency) linear interpolation between age control points using the clam package for R (Blaauw 2010). In several cases, the surface of the mire or lake sediment was assigned a date corresponding approximately to the date when the site was sampled. In a few cases, basal dates were estimated by extrapolation where the base was not far below the lowermost age control point.

Selected datasets used in this analysis are shown in Figure 3 and all of the data points are plotted against time in Figure $4 \mathrm{~d}$.

To facilitate comparisons between sequences, the Betula undiff. time series were rescaled so that Betula proportions ranged from - 1 to 1 in each case. This step was intended to compensate for the fact that some sites have a smaller range of Betula proportions than others, which presumably reflects ecological realities in many instances, but in other cases it may be an artefact of the taphonomy of the site (e.g. lake 
records such as Breiðavatn, and the marine record from Reykjarfjörður, typically have lower maxima for Betula than are found in many peat records).

Some records are better resolved than others, meaning that they contribute more data points to Figure 4d (e.g. compare older datasets such as Borgarmýri 1 and 2 with more recent datasets such as Breiðavatn and Helluvaðstjörn in Figure 3). To compensate for this, the irregular time series were converted to regular time series by calculating the weighted average of the data points within contiguous 100 -year-long windows. Figure $4 \mathrm{e}$ shows the mean of these scaled values against time. Figure $4 \mathrm{f}$ further summarizes the data by plotting, for each window, the proportion of records where the Betula proportion is above (white bars) or below (grey bars) its long-term mean at that site.

\section{Results}

Palaeoenvironmental records are unevenly distributed within Iceland (Figure 1). Sediment sections are concentrated in the south and north, and are concentrated around volcanic zones. This pattern reflects the broad distribution of current deep soils and the more frequent occurrence of tephra layers, which are used to determine rates of sediment accumulation. These areas also tend to have experienced the highest levels of erosion due to the greater depth of sediment available to erode and the low cohesion of the andisols, which are the dominant soil type in these areas. Pollen records are concentrated in the north and the west of the country, with a large gap in the central highland desert and another in southeastern Iceland which partly reflects the scarcity of lakes and mires on the well-drained sandur plains of this region; the few sites that do exist here (e.g. Ketilstaðir: Erlendsson et al., 2009; Papey: Buckland et al. 1995; Edwards et al., 2004) failed to meet the criteria for inclusion in our analysis. 
Figure 2 illustrates the range of geomorphic change over the 2.5 ka using selected records. The sites at Skaftár 172, Ytri-Skógar and Reykjanes located in the south of Iceland show generally higher SeARs than the northern sites of Hörgardalur, Svínavatn 1 and Svalbarð both before and after landnám. This pattern is representative of a general difference between sites in southern and northern Iceland. The period of highest SeAR in the six records shown in Figure 2 always occurs after c. 1200 AD. Where there is no Landnám tephra present, as at Svalbarð, increases in SeAR appear to occur later than in other sections where there is better chronological control. Profiles where there is relatively limited change until several centuries after landnám, after which there is an order-of-magnitude increase in SeAR (Ytri-Skógar, Reykjanes 1), may represent the crossing of site-dependant local slope-stability thresholds.

Figure $4 \mathrm{a}$ is a plot of all of the SeAR data from the 35 sites against time. The chronological resolution of the data is markedly better after landnám than before. Siteto-site variability in SeAR (indicated by the scatter of grey horizontal lines) is quite substantial even prior to landnám, with a few sites showing high SeAR, but the individual trajectories of SeAR become much more variable after landnám (as illustrated by the examples in Figure 2).

The solid curve in Figure 4b shows the century-by-century variation in the mean SeAR. There is little variation in mean SeAR before Landnám, but immediately after there is a rapid increase in SeAR which is sustained right through to the late $19^{\text {th }}$ century. The sharp increase in SeAR during the $10^{\text {th }}$ century $\mathrm{AD}$ and subsequent accelerations during the $16^{\text {th }}$ and $19^{\text {th }}$ centuries stand out above the overall rising trend. 
Figure 4c shows the proportion of sites during each time window which are above or below average for that site. This confirms that, before c. AD 900, almost every site shows low SeAR relative to its long-term mean. After AD 900, the proportion of sites showing above-average SeAR increases, and this proportion climbs more or less steadily towards the present day. However, even in the $20^{\text {th }}$ century AD ten out of 32 sites show belowaverage SeAR. This reflects high site-to-site variation in the temporal pattern of SeAR, as illustrated in Figure 2.

\section{Betula pollen}

Figure 3 shows selected Betula pollen records. While most records show a decline in Betula pollen proportions after settlement, a small number of records behave differently. For example, Reykjanes shows low Betula proportions before settlement followed by higher proportions from c. AD 1300 to 1600 . Another exception is the record from Breiðavatn, where Betula undiff. proportions decline after settlement but begin to increase again after AD 1400. In this case this pattern is clearly an artefact of the reduced taxonomic precision of our analysis; in the original publication, GathorneHardy et al. (2009) demonstrated that the increase is due to enhanced inputs of damaged grains, inferred to have been reworked from catchment soils. The dashed line in Figure 3 shows their published curve, which excluded damaged grains. A similar explanation may account for comparable trends at Borgarmýri, Hallormsstaður, and two other records not shown in Figure 3 (Moldhaugar and Solheimagerði), but in these cases the analysts did not discriminate between pristine and damaged grains.

Figure $4 \mathrm{~d}$ shows the Betula pollen values drawn from the 25 usable records, scaled from -1 to 1 within each record, with a Lowess curve (bandwidth $=250$ ) indicating the general trend in the data. This curve over-represents sites that are well-resolved, i.e. that contain a large number of samples. Figure 4e accounts for this bias by giving each 
site equal weight in calculating the mean century-by-century change in Betula pollen abundance. This curve shows a declining trend in birch pollen proportions beginning well before settlement. There is a small step-like decline between the $9^{\text {th }}$ and $10^{\text {th }}$ centuries $\mathrm{AD}$, followed by a slight resurgence during the $12^{\text {th }}$ century, then a further decline during the $13^{\text {th }}$ century. Thereafter, Betula pollen proportions remain low on average. By comparison with the equivilent SeAR curve (Figure 4b) the decline in Betula proportions is more gradual in the centuries after settlement but slows down after the $13^{\text {th }}$ century, whereas SeARs continue to rise.

There is very substantial noise throughout the dataset with many records indicating high (even maximal) proportions of Betula pollen within the last 500 years; but during that period, there is a comparatively large number of records showing minimal presence of Betula pollen, which reduces the overall average. Figure $4 \mathrm{f}$ illustrates this site-to-site variation. Before landnám, most records show above-site-average Betula proportions, although in most centuries there are a small number of sites which disagree. During the $8^{\text {th }}$ to $12^{\text {th }}$ centuries $A D$ the balance shifts and by the $13^{\text {th }}$ century almost all sites show below-average Betula proportions.

Figure 5 shows mean scaled SeARs for each century plotted against mean scaled Betula proportions. Before the $9^{\text {th }}$ century AD SeARs are low and change little, but there is an overall downward trend in Betula proportions. Between AD 800 and AD 1000 there is a rapid transition to higher SeARs and lower Betula proportions. Increases in SeAR precede large declines in Betula by approximately 100 years. Betula gradually declines until AD 1400, accompanied by a small increase in SeAR. From the $15^{\text {th }}$ century onwards SeAR increases substantially, but there is little further reduction in Betula proportions. There is a clear separation between the two main areas occupied on Figure 5 (indicated by dashed ovals), an earlier, pre-landnám period of high Betula proportions and low 
sediment accumulation rates, and a later, post-landnám period of lower Betula proportions and high sediment accumulation rates.

\section{Discussion}

Our analysis allows us to address four main questions, which provide the structure for our discussion:

1. Is the degree of environmental change at colonization sufficient to define the start of the palaeoanthropocene in Iceland?

2. What processes are capable of creating legacies in environmental records?

3. How will these changes be preserved in the long term geological record?

4. How comparable is Iceland to other islands?

These questions allow us to address wider debates about the best spatial and temporal scales at which we should seek evidence for anthropogenic impacts and the importance of defining 'start dates' (cf. Smith and Zelder, 2013; Foley et al., 2013).

Rapid increases in sediment accumulation rate (SeAR) have been correlated with the arrival of humans in southern Iceland, although with local-scale chronological differentiation (Dugmore and Buckland, 1991; Dugmore et al. 2007, 2009; Streeter et al., 2012). In contrast, despite its colonisation at the same time and the broadly similar pattern of settlement, this correlation is absent in northern Iceland, where large increases in soil erosion occur later, although this may reflect the poorer chronological control there due to fewer tephra layers (Ólafsdóttir and Gudmundsson, 2002; Brown et al., 2012). Rapid reductions in woodland cover over Iceland as a whole, from an estimated $27 \%$ immediately before landnám to today's c. $1 \%$, have typically been attributed to clearance for grazing by the first few generations of colonists (Hallsdóttir, 1996; Vickers et al., 2011), but some studies have shown that woodland cover in some 
areas away from settlement sites remained in place until at least AD 1300, four centuries after the advent of settlement (Lawson et al., 2007; Church et al., 2007; Gathorne-Hardy et al., 2009; Sigurmundsson et al., 2014).

\section{Defining the start of the palaeoanthropocene in Iceland}

Our analysis of two proxy indicators of environmental change in Iceland (Figure 4) shows that they do respond to the arrival of humans, but the pattern is noisy and complex. The SeAR record (Figure. 4b) has a comparatively strong signal of landnám impacts with, on average a sharp increase in SaER during the century following settlement, but there is significant variation from site to site and a sizeable minority of records show no change until several centuries after landnám (Figure 2). The Betula pollen data are still more equivocal. Betula proportions were steadily declining at the majority of sites over several centuries prior to settlement, but this was not true everywhere, and there were shorter-term fluctuations at some sites (e.g. the AD 600800 increase in Betula proportions discussed by Erlendsson and Edwards 2009, which they attributed to both increased pollen production, and to increased density and areal extent of woodland in response to favourable climatic conditions). Although there is, on average and at many individual sites, a pronounced fall in Betula proportions in the century after landnám at many sites, falls of similar magnitude occur prior to landnám. There is also a great deal of site-to-site variation in the pattern of Betula proportions over time. Well-resolved lake records such as Helluvaðstjörn (Lawson et al., 2007), recruiting pollen from a large catchment with minimal reworking, are perhaps most representative of the overall trend, but in Iceland pollen records at lake sites are outnumbered by those from mire sites (Figure 1) which, having more local taphonomic signatures, are perhaps more revealing of the true spatial heterogeneity of the process of woodland decline. 
Based on the case of Iceland we can suggest two reasons why it may be difficult to recognise the onset of the palaeoanthropocene in environmental records. Firstly, spatial and temporal patterns of environmental change vary widely, even when humans arrive within a very short interval of time. This makes defining a precise start date for the onset of major human modification of environments over large areas difficult, perhaps even counter-productive, as it risks underestimating more localised impacts. Secondly, long-term underlying environmental trends may affect our ability to identify unequivocal human impacts. For example, the changes in Betula proportions before settlement may be related to a century-scale periods of climatic change (Erlendsson and Edwards, 2009; Larsen et al., 2012; Geirsdóttir et al., 2013) overlaid on longer-term patterns including declining northern hemisphere summer insolation, and perhaps the progressive paludification of the landscape (Hallsdóttir and Caseldine, 2005).

The record from Iceland, which represents an unusually favourable place in which to study past human impacts, suggests it may be futile to try to define a start date for significant human impacts based on changes in individual environmental proxies. However, one potential way to separate natural and human signals is too look for differences in spatial patterns. For example, we would expect woodland decline as a result of climatic cooling to affect areas that are marginal for Betula growth. By contrast, woodland clearance around settlements would produce a pattern of greatest change around ecologically more favourable areas. On detailed inspection this is bourne out in the palynological, archaeobotanical and historical data from at least some regions of Iceland (Hallsdóttir, 1987; Dixon, 1997; Church et al., 2007; Sigurmundsson et al., 2014), which do indeed suggest that deforestation was most rapid close to landnám-era farms, and that it proceeded more slowly in more remote districts. 


\section{Processes capable of recording the Anthropocene in palaeoenvironmental}

\section{records}

There are a variety of ways in which people can create alternative environmental states, typically for the purpose of 'niche' construction (Smith and Zelder, 2013). The processes may be broadly grouped into introductions, extirpations and changes in environmental patterns. The creation of these alternative environmental states, such as the one seen in Figure 5, could be considered an indicator of a local onset of the Paleaoanthropocene.

In Iceland people introduced a suite of domestic animals including cattle, horses, sheep, goats, pigs and dogs, and their commensals and parasites such as the dung beetle Aphodius lapponum and sheep louse Damalinia ovis (Buckland and Panagiotakopulu 2005; cf. Erlendsson et al., 2009). Some plants have been deliberately introduced, such as barley (Hordeum vulgare) in earliest times (which can only survive with active human intervention), and the Nootka lupin (Lupinus nootkatensis) in modern times (an invasive species capable of extensive dispersal without human assistance). Norse-age (after c. AD 870) anthropogenic introductions created a terrestrial mammal island fauna, something that had been absent (with the exception of the Arctic fox and occasional Polar Bear) probably since the Pliocene Epoch, c. 3.5-3 Ma, when there is fossil evidence for the presence of a small deer (Grímsson and Símonarson, 2008).

Due to the lack of endemic species, limited local extirpations as a result of human settlement have generally involved an alteration of range rather than the demise of a species. Thus, walrus (Odobenus rosmarus) once occupied some Icelandic beaches, but now its range has contracted across the Atlantic to the north and west. Perhaps the most infamous extirpation (and indeed worldwide extinction) took place in 1844, when the last known great auks (Pinguinus impennis) were killed on Eldey, a small offshore island (Crofford 1989). 
People can modify existing environmental patterns and create new habitats through, for example, forest clearance. This may be achieved with low levels of technology involving axe or fire (although there is little definitive evidence of woodland clearance by burning in the palaeoenvironmental record in Iceland). Animal husbandry may have provided a continuing mechanism for environmental change in Iceland through the introduction of domestic stock in general and pigs, sheep and goats in particular - cattle and horses were present, but they were less abundant (McGovern et al., 2007; Lucas, 2009; Zori et al., 2013). Once established, introduced species could drive long-term modifications of the quality and distribution of both surface vegetation patterns and they could influence slope and erosion processes. In Iceland, anthropogenic vegetation change combined with climatic deterioration has reduced woodland from c. $27 \%$ of the land area to c. $1 \%$ today. Grazing pressures have played a key role in soil erosion, a second great pattern of environmental change in Iceland since human colonization. Some $15-30 \%$ of Iceland's pre-settlement soil and vegetation cover has been removed by enhanced surface erosion (Arnalds et al., 2001). In Iceland, soil erosion tends to proceed as a total loss of soil in discrete areas, rather than as a more diffuse loss of soil quality, and erosion is thus most usefully measured in hectares rather than as a loss of tonnes per hectare. In terms of area affected it is probably equivalent to that of woodland removal, but it is a process that is more difficult to recognise in the environmental record because of the selective removal of potential 'archives' from the system.

\section{Preserving records of change}

The longevity (in geological terms) of archives recording the onset of the Anthropocene, or even regional Palaeoanthropocenes (Foley et al., 2013), has been much debated as a criterion for acceptance of one or more 'golden spikes'. In Iceland our record shows a change from an environment with high incidence of Betula pollen and low levels of 
aeolian sediment accumulation to low incidences of Betula pollen and high levels of aeolian sediment accumulation, with the main transition between these two states lasting about a century (Figure 5). During the Quaternary superficial deposits across the whole of Iceland have been repeatedly eroded by icesheets and, on the few nunataks, periglacial processes (Hubbard et al., 2006), suggesting that marine records will have the best chance of survival on geological timescales. However, marine records are likely to be insensitive to spatially-dispersed human impact. The one marine pollen record considered here (Reykjafjörður, Figure 3) comes from a fjord which was likely glaciated (Andrews et al., 2001). Perhaps surprisingly given its inshore location, it shows an atypical pattern of change, probably due to taphonomic issues. Likewise, marine records of sediment accumulation appear more sensitive to climatic changes than anthropogenic impacts (e.g. Jennings et al., 2001). Predicted temperature changes could result in the effective disappearance of all major Icelandic glaciers within two centuries (Björnsson and Pálsson 2012). In that warmer world, terrestrial and lacustrine environmental records of the impacts of landnám could conceivably survive for centuries to millennia as part of the geological record. There would also be a reversion to pre-Quaternary Earth surface processes; an effective lack of new glacial landforms, glacial or glaciofluvial sediments, very limited formation of palagonite and a reversion to a geological record dominated by the accumulation of subaerial lava flows and reduced volcanic explosivity. These changes would perhaps leave a more enduring geological legacy than the more direct changes as a result of human impacts represented by the records discussed here. This suggests that if our main concern in defining the Palaeoanthropocene is to understand the nature of human change then a geological criterion for the preservation of records may be too rigorous. 


\section{Comparisons with other islands and continents}

The final point of our discussion is to consider the extent to which our analysis of the visibility of the onset of the (Palaeo-)Anthropocene in Iceland is specific to this particular case, and how it compares with other islands, or indeed more widely to continental regions. In this context the recognition of pre-existing vulnerabilities is vital. Particular human activities such as pastoralism, agriculture or industrialisation may ultimately drive wholesale environmental change, but the pace at which these processes bring about alternative environmental states depends on the intrinsic properties of natural systems that condition their response to such drivers.

The small spatial scale of many islands, their lack of internal barriers and the exaggerated ecological release of anthropogenic introductions means that human impacts can rapidly affect the whole ecosystem and become a dominant process in Earth surface systems, such that a distinct Anthropocene may subsequently be recognisable in local palaeoenvironmental records (Rick et al., 2013). In Iceland the capability of humans to modify the environment was delivered abruptly and as a fully-formed package. The long-term ecological context of Iceland is important to understanding what happened next.

Islands are not simple microcosms of continental areas; for example, remote oceanic islands in low latitudes are characterised by their ecological isolation which has resulted in low immigration rates and species poverty. Very low chances of colonisation mean that few species arrive on the islands, interspecies competition is limited and the chances of new introductions of vigorous invasive species are low. Combine this with thermal buffering from the surrounding ocean, and the result is high ultimate stability (biotal preservation over 1-30 Ma), high ultimate diversity (uniqueness of the biota) and low proximate diversity (species numbers) (Cronk, 1997, Table 4). When island 
isolation is broken by human intervention, the interplay of contrasting diversities and long term stability can result in very low levels of proximate stability (or high levels of ecological vulnerability) (Table 4).

Iceland has ecological vulnerabilities which differ from those of lower-latitude islands such as those in the Central Atlantic, Polynesia, the Caribbean, and California (e.g. Cronk, 1997; Flenley and Bahn, 2002; Edwards and Bird, 2007; Rick et al., 2013). Perhaps the most significant is that, in comparison with continental areas at similar latitudes, Iceland has a depauperate biota which is a small subset of that found in North West Europe and which lacks endemic species (Buckland and Dugmore, 1991; Buckland et al., 1998). This is as a result of repeated Quaternary glaciations that both extirpated species within Iceland and allowed only a brief window for recolonization during interglacials, as a consequence of meltwater pulses, which lowered ocean salinity and ice-rafting. This contrasts with the ecological uniqueness of low-latitude oceanic islands that could be considered so sensitive to anthropogenic disturbance that their histories of human impact offer little in wider assessments of vulnerabilities to human drivers of change in continental areas.

Thus we can observe the stepwise change in some environmental indicators at landnám due to the rapid introductions of domestic animals, but we can also understand the delay of noticeable change in environmental processes and their proxy records. Owing to their different histories of environmental change and colonization, North Atlantic islands in general and Iceland in particular had greater eve-of-settlement resilience compared to low latitude oceanic islands. Contrasting resilience is likely to be a major factor in the contrasting delays between the arrival of humans and the manifestation of change in environmental records. 


\section{Conclusions}

The human colonization of Iceland resulted in changes which lie outside the ambit of natural environmental change, such as the introduced mammalian biota, the maintenance of artificially high numbers of livestock and the creation of artificial structures. In contrast, some island-wide effects such as soil erosion and deforestation have similarities with natural change produced by climate fluctuations. The pattern of change may be different, with, for example, trees cleared earliest from the most favourable areas for cultivation and grazing, but detection of such subtle patterns demands a dense network of well-placed records, which barely exists in Iceland despite seven decades of palynological research.

Furthermore, our analysis shows that the pattern and timing of the onset vary depending on the particular palaeoenvironmental proxy in question. A clear transitional boundary does not obviously exist in the Icelandic record taken as a whole, and it would be difficult to identify the beginning of human impact without additional information (in this case, historical and archaeological information and the fortuitous presence of the Landnám tephra). Consequently, a type site for the onset of the palaeoanthropocene in Iceland at a particular time has limited use, because the change is time-transgressive even within Iceland. Furthermore, most of our records are unlikely to be preserved over geological timescales. Those changes that are preserved are likely to tell future generations more about the geomorphological consequences of climatic changes that have yet to play out, than about the first millennium or more of human impacts on Iceland.

We have also argued that some of the proxy records incorporated in our analysis are likely to be compromised, for example by the presence of reworked Betula pollen that was not identified as such. The inevitable noise in palaeoecological reconstructions can 
hinder attempts to identify objectively any thresholds of human impact. To argue for a clear definition of the palaeoanthropocene based on observable characteristics of the geological record alone, even locally and even in the favourable case of Iceland, would therefore appear to be a lost cause.

In Iceland, made resilient by the impact of glaciations which resulted in island ecologies that are a subset of continental ones, we see delay between the change of process and the manifestation of those changes in a majority of our environmental archives, despite the nature, scale and speed of humans colonization. This is in contrast to small, remote low-latitude oceanic island environments where changes in process brought on by people can cause rapid changes in environmental indicators.

People introduce new processes to the environment (by direct and indirect actions) that may create a lasting legacy. The roots of historical impact on the Earth lie in a change of process, which may not immediately manifest itself in the planetary record. Although in Iceland the consequences of this change in process (enhanced erosion) become most apparent in the $18^{\text {th }}$ century, it was the introduction of grazing animals some 900 years previously which initiated the change. We would argue that 'reference sites' that exemplify the change of process that defines the Anthropocene may have value in understanding the extent and character of human impact over the long term, thereby underpinning the argument for erecting the Anthropocene as a distinct geochronological unit, even if there is little practical value in focusing on defining the onset of major impacts, which is in general likely to be gradual and diachronous.

\section{Acknowledgements}

We would like to gratefully acknowledge the support of the Carnegie Trust for the Universities of Scotland, the National Science Foundation of America (through grant 
1202692 'Comparative Island Ecodynamics in the North Atlantic' and grant 1249313

'Tephra layers and early warning signals for critical transitions'), and the Leverhulme Trust (Study Abroad Fellowship to AJD). We would also like to thank the constructive comments of two anonymous reviewers.

\section{References}

Andrews JT, Caseldine C, Weiner NJ and Hatton J (2001) Late Holocene (ca. 4 ka) marine and terrestrial environmental change in Reykjarfjördur, north Iceland: climate and/or settlement? Journal of Quaternary Science 16: 133-143.

Andrews JT, Geirsdóttir A, Hardardóttir J, Principato S, Grönvold K, Kristjansdóttir GB, Helgadóttir G, Drexier J and Sveinbjörnsdóttir A. (2002) Distribution, sediment magnetism and geochemistry of the Saksunarvatn (10 180 \pm 60 cal. yr BP) tephra in marine, lake, and terrestrial sediments, northwest Iceland. Journal of Quaternary Science, 17(8): 731-745.

Arnalds O (2000) The Icelandic 'rofabard' soil erosion features. Earth Surface Processes and Landforms, 25: 17-28.

Arnalds O, Thorarinsdottir EF, Metusalemsson S, Jonsson A, Gretarsson E and Arnason A (2001) Soil Erosion in Iceland. Reykjavík: Soil Conservation Service and Agricultural Research Institute, pp. 121.

Bartley DD (1973) The stratigraphy and pollen analysis of peat deposits at Ytri Baegisa near Akureyri, Iceland. GFF 95: 410-414.

Björnsson H and Pálsson F. (2008) Icelandic glaciers. Jokull 58: 365-386. 
Blaauw M. (2010) Methods and code for 'classical' age-modelling of radiocarbon sequences. Quaternary Geochronology 5: 512-518.

Boygle J. (1999) Variability of tephra in lake and catchment sediments, Svínavatn, Iceland. Global and Planetary Change 21: 129-149.

Braje TJ and Erlandson JM. (2013) Human acceleration of animal and plant extinctions: A Late Pleistocene, Holocene, and Anthropocene continuum. Anthropocene 4: 14-23.

Brochmann C, Gabrielsen TM, Nordal I, Landvik JY and Elven R (2003) Glacial survival or tabula rasa? The history of North Atlantic biota revisited. Taxon 52: 417-450.

Brown JL, Simpson IA, Morrison SJL, Adderley WP, Tisdall E and Vésteinsson O (2012) Shieling areas: historical grazing pressures and landscape responses in Northern Iceland. Human Ecology 40: 81-99.

Buckland PC, Edwards KJ, Blackford JJ, Dugmore AJ, Sadler JP and Sveinbjarnardóttir G (1995) A question of Landnám: pollen, charcoal and insect studies on Papey, eastern Iceland. In: Butlin R and Roberts N (eds) Ecological relations in historical times: human impact and adaptation. Oxford: Blackwell, pp. 245-264.

Buckland PC, Dugmore AJ, Sadler JP (1998) Palaeoecological evidence for human impact on the North Atlantic islands. Boletim do Museu Municipal do Funchal (Historia Natural), Supplement 5, 89-108.

Buckland PC, Panagiotakopulu E (2005) Archaeology and the palaeoecology of the Norse Atlantic Islands: a review. In: Viking and Norse in the North Atlantic. Proceedings of the 14th Viking Congress, Tórshavn 2001. Annales Societatis Scientiarum Færoensis, Supplementum 44: 167-181. 
Caseldine C (2001) Changes in Betula in the Holocene record from Iceland - a palaeoclimatic record or evidence for early Holocene hybridisation? Review of Palaeobotany and Palynology 117: 139-152.

Caseldine C and Hatton J (1994) Interpretation of Holocene climatic change for the Eyjafördur area of northern Iceland from pollen-analytical data: Comments and preliminary results. Environmental change in Iceland: Münchener Geographische Abhandlungen, Reihe B, 12, pp. 41-42.

Church MJ, Dugmore AJ, Mairs KA, Millard AR, Cook GT, Sveinbjarnardottir G, Ascough PA and Roucoux KH (2007) Charcoal production during the norse and early medieval periods in Eyjafjallahreppur, southern Iceland. Radiocarbon 49: 659-672.

Crofford E (1989) Gone Forever: The Great Auk. New York: Crestwood House

Cronk QCB (1997) Islands: stability, diversity, conservation. Biodiversity and Conservation 6: 477-493.

Crutzen PJ. (2002) Geology of mankind. Nature 415: 23-23.

Dixon AT (1997) Landnám and changing landuse at Háls, southwest Iceland: a palaeoecological study. Unpublished MSc thesis, University of Sheffield.

Dugmore AJ (1987) Holocene glacial fluctuations around Eyjafjallajökull, South Iceland. Ph.D. Thesis, University of Aberdeen, UK.

Dugmore AJ and Erskine CC (1994) Local and regional patterns of soil erosion in southern Iceland. Environmental change in Iceland: Münchener Geographische Abhandlungen, Reihe B, 12, pp. 63-78. 
Dugmore AJ, Cook GT, Shore JS, Newton AJ, Edwards KJ, Larsen G (1995) Radiocarbon dating tephra layers in Britain and Iceland. Radiocarbon 37: 379-388.

Dugmore AJ, Gísladóttir G, Simpson IA and Newton AJ (2009). Conceptual Models of 1200 Years of Icelandic Soil Erosion Reconstructed Using Tephrochronology. Journal of the North Atlantic 2: 1-18.

Dugmore AJ, Newton AJ, Larsen G and Cook GT (2000) Tephrochronology, environmental change and the Norse settlement of Iceland. Environmental Archaeology 5: $21-34$.

Dugmore AJ and Buckland PC (1991) Tephrochronology and late Holocene soil erosion in Southern Iceland. In: Maizels JK and Caseldine C (eds) Environmental Change in Iceland: Past and Present. Dordrecht: Kluwer Academic, pp. 147-159.

Dugmore AJ, Church MJ, Buckland PC, Edwards KJ, Lawson IT, McGovern TH, Panagiotakopulu E, Simpson IA, Skidmore P and Sveinbjarnardottir G (2005) The Norse landnam on the North Atlantic islands: an environmental impact assessment. Polar Record 41: 21-37.

Dugmore AJ, Church MJ, Mairs K-A, McGovern TH, Perdikaris S and Vesteinsson O (2007) Abandoned farms, volcanic impacts, and woodland management: Revisiting pjorsardalur, the "Pompeii of iceland". Arctic Anthropology 44: 1-11.

Dugmore AJ, Newton AJ, Smith KT and Mairs K-A (2013) Tephrochronology and the late Holocene volcanic and flood history of Eyjafjallajokull, Iceland. Journal of Quaternary Science 28: 237-247. 
Edgeworth M, deB Richter D, Waters C, et al. (2015) Diachronous beginnings of the Anthropocene: The lower bounding surface of anthropogenic deposits. The Anthropocene Review 2: 33-58.

Edwards KJ (2005) "On the windy edge of nothing": a historical human ecology of the Faroes Islands. Human Ecology 33: 585-596.

Edwards KJ (2012) Was the peopling of Iceland a trickle, a steady stream or a deluge? Norwegian Archaeological Review 45: 220-223.

Edwards KJ and Bird MJ (eds, 2007) Holocene environmental change: lessons from small oceanic islands. Earth and Environmental Science Transactions of the Royal Society of Edinburgh 98, issue 1. Edinburgh: Royal Society of Edinburgh/Cambridge: Cambridge University Press, 125 pp.

Edwards KJ, Dugmore AJ and Blackford JJ (2004) Vegetational response to tephra deposition and land use change in Iceland — a modern analogue and multiple working hypothesis approach to tephropalynology. Polar Record 40: 113-120.

Edwards KJ, Erlendsson E and Schofield JE (2011) Is there a Norse 'footprint' in North Atlantic pollen records. In: Sigmundsson S, Holt A, Sigurðsson G, Ólafsson G and Vésteinsson 0 (eds) Viking settlements and society: papers from the Sixteenth Viking Congress, Reykjavík and Reykholt, 16-23 August 2009. Reykjavík: Hið íslenska fornleifafélag and University of Iceland Press, 65-82.

Edwards KJ, Erlendsson E and Schofield JE (forthcoming) Landnám and the North Atlantic flora. In: Panagiotakopulu E and Sadler JP (eds) North Atlantic island biota: aspects of the past, choices for the future. Chichester: Wiley-Blackwell. 
Einarsson P (1957a) Tvö frjólinurit úr íslenskum mómýrum. Ársrit Skógræktarfélags Íslands 1957: 89-97.

Einarsson P (1957b) Frjógreining fjörumós úr Seltjörn. Náttúrufræðingurinn 26: 194198.

Einarsson P (1961) Pollenanalytische Untersuchungen zur spät- und postglazialen Klimageschichte Islands. Sonderveröffentlichungen des Geologischen Institutes der Universität Köln 6: 52 pp.

Einarsson P (1963a) Vitnisburður frjógreiningar um grðúr, veðurfar og landnám á Íslandi. Saga 1962: 442-469.

Einarsson P (1963b) Pollen-analytical studies on vegetation and climate history of Iceland in late and post-glacial times. In: Löve A and Löve D (eds) North Atlantic biota and their history. Oxford: Pergamon Press, pp. 355-365.

European Pollen Database. http://www.europeanpollendatabase.net/ (accessed $14 / 10 / 14)$.

Erlendsson E (2007) Environmental change around the time of the Norse settlement of Iceland. Unpublished $\mathrm{PhD}$ thesis, University of Aberdeen.

Erlendsson E and Edwards KJ (2009) The timing and causes of the final pre-settlement expansion of Betula pubescens in Iceland. The Holocene 19: 1083-1091.

Erlendsson E, Edwards KJ and Buckland PC (2009) Vegetational response to human colonisation of the coastal and volcanic environments of Ketilsstaðir, southern Iceland. Quaternary Research 72: 174-187. 
Flenley J and Bahn P (2002) The Enigmas of Easter Island. Oxford: Oxford University Press, 274pp.

Foley SF, Gronenborn D, Andreae MO, Kadereit JW, Esper J, Scholz D, Pöschl U, Jacob DE, Schöne BR, Schreg R, Vött A, Jordan D, Lelieveld J, Weller CG, Alt KW, GaudzinskiWindheuser S, Bruhn K-C, Tost H, Sirocko F and Crutzen PJ (2013) The Palaeoanthropocene - The beginnings of anthropogenic environmental change. Anthropocene 3: 83-88.

Gale SJ and Hoare PG (2012) The stratigraphic status of the Anthropocene. The Holocene 22: $1491-1494$.

Gathorne-Hardy FJ, Erlendsson E, Langdon PG and Edwards KJ (2009) Lake sediment evidence for late-Holocene climate change and landscape erosion in western Iceland. Journal of Paleolimnology 42: 413-426.

Geirsdóttir Á, Miller GH, Larsen DJ, and Ólafsdóttir S. (2013) Abrupt Holocene climate transitions in the northern North Atlantic region recorded by synchronized lacustrine records in Iceland. Quaternary Science Reviews 70: 48-62.

Gísladóttir G, Erlendsson E, Lal R and Bigham J (2010) Erosional effects on terrestrial resources over the last millennium in Reykjanes, southwest Iceland. Quaternary Research 73: 20-32.

Gudmundsdóttir ER, Larsen G and Eiríksson J. (2011) Two new Icelandic tephra markers: The Hekla Ö tephra layer, 6060 cal. yr BP, and Hekla DH tephra layer, similar to 6650 cal. yr BP. Land-sea correlation of mid-Holocene tephra markers. Holocene 21: 629-639. 
Grímsson F and Símonarson LA. (2008) Upper Tertiary non-marine environments and climatic changes in Iceland. Jökull 58: 303-314.

Grönvold K, Oskarsson N, Johnsen SJ, Clausen HB, Hammer CU, Bond G and Bard E (1995) Ash layers from Iceland in the Greenland GRIP ice core correlated with oceanic and land sediments. Earth and Planetary Science Letters 135: 149-155.

Hallsdóttir M (1984) Frjógreining tveggja jarðvegsniða á Heimaey. Árbók hins íslenzka fornleifafélags 1983: 48-68.

Hallsdóttir M (1987) Pollen analytical studies of human influence on vegetation in relation to the landnám tephra layer in southwest Iceland. $\mathrm{PhD}$ thesis, Lund University.

Hallsdóttir M (1995) On the pre-settlement history of Icelandic vegetation. Icelandic Agriculture Science 9: 17-29.

Hallsdóttir M (1996) Frjógreining. Frjókorn sem heimild um landnámid. In: Grímsdóttir G (ed.) Um Landnám Á Íslandi. Reykjavík: Societas scientiarum Islandica, pp. 123-134.

Hallsdóttir M and Caseldine CJ (2005) The Holocene vegetation history of Iceland, stateof-the-art and future research. Developments in Quaternary Sciences 5: 319-334.

Haflidason H, Larsen G, Ólafsson G (1992) The recent sedimentation history of Thingvallavatn, Iceland. Oikos 64: 80-95.

Hubbard A, Sugden DE, Dugmore A, Norddahl H and Pétursson HG (2006) A modelling insight into the Icelandic Last Glacial Maximum ice sheet. Quaternary Science Reviews 25, 17-18: 2283-2296 
Jennings AE, Hagen S, Hardardottir J, Stein R, Ogilvie AEJ, Jonsdóttir I (2001)

Oceanographic change and terrestrial human impacts in a post AD 1400 sediment record from the southwest Iceland shelf. Climatic Change 48: 83-100.

Jónsson SA (2009) Vegetation History of Fljótsdalshérað during the last 2000 years. University of Iceland. Unpublished MSc thesis.

Jónsson SA, Eggertson Ó and Ingólfsson Ó (2012) Skógarsaga Fljótsdalshéraðs síðustu 2000 árin. Náttúrufræðingurinn 82: 87-97.

Karlsdóttir L, Thórsson ÆT, Hallsdóttir M, Sigurgeirsson A, Eysteinsson T, AnamthawatJónsson K (2007) Differentiating pollen of Betula species from Iceland. Grana 46: 78-84.

Karlsdóttir L, Hallsdóttir M, Thórsson ÆTh, Anamthawat-Jónsson K (2012) Early Holocene hybridization between Betula pubescens and B. nana in relation to birch vegetation in Southwest Iceland. Review of Palaeobotany and Palynology 181: 1-10.

Karlsson G. (2000) Iceland's 1000 years: History of a Marginal Society, London: Hurst \& Company.

Larsen DJ, Miller GH, Geirsdóttir Á, et al. (2012) Non-linear Holocene climate evolution in the North Atlantic: a high-resolution, multi-proxy record of glacier activity and environmental change from Hvítárvatn, central Iceland. Quaternary Science Reviews 39: 14-25.

Larsen, G., 1984 Recent volcanic history of the Veidivötn fissure swarm, Southern Iceland. An approach to volcanic risk assessment. Journal of Volcanology and Geothermal Research 22, 33-58.

Larsen, G., 2000. Holocene eruptions within the Katla volcanic system, south Iceland: Characteristics and environmental impact. Jökull, 49, 1-28. 
Larsen G and Thórarinsson S (1984) Kumlateigur í Hrífunesi í Skaftártungu IV. Árbók hins íslenska fornleifafélags: 31-47

Larsen G, Dugmore A and Newton A. (1999) Geochemistry of historical-age silicic tephras in Iceland. Holocene 9: 463-471.

Larsen G, Newton AJ, Dugmore AJ, Vilmundardóttir EG. (2001) Geochemistry, dispersal, volumes and chronology of Holocene silicic tephra layers from the Katla volcanic system, Iceland. Journal of Quaternary Science 16: 119-132.

Larsen G, Gudmundsson MT (2014) Bárðarbunga system. Catalogue of Icelandic Volcanos (forthcoming). Available at http://www.vedur.is

Lawson IT, Gathorne-Hardy FJ, Church MJ, Newton AJ, Edwards KJ, Dugmore AJ and Einarsson A (2007) Environmental impacts of the Norse settlement: palaeoenvironmental data from Myvatnssveit, northern Iceland. Boreas 36: 1-19. Lawson IT (2009) The palaeoenvironment of Mývatnssveit during the Viking Age and early Medieval Period. In: Lucas G (ed.) Hofstaðir: excavations of a viking age feasting hall in north-eastern Iceland. Reykjavík: Institute of Archaeology, pp. 26-54.

Lowe DJ (2011) Tephrochronology and its application: a review. Quaternary Geochronology 6: 107-153.

Lewis SL and Maslin MA. (2015) Defining the Anthropocene. Nature 519: 171-180.

Lucas G (ed., 2009) Hofstaðir.Excavations of a Viking Age feasting hall in north-eastern Iceland. Reykjavík: Institute of Archaeology, 440pp. 
Mäkelä EM (1996) Size distinctions between Betula pollen types - a review. Grana 35: $248-256$.

McGovern TH, Vésteinsson O, Friðriksson A, Church MJ, Lawson IT, Simpson IA, Einarsson A, Dugmore AJ, Cook GT, Perdikaris S, Edwards KJ, Thomson A, Adderley WP, Newton AJ, Lucas G, Edvardsson R, Aldred O and Dunbar E (2007) Landscapes of settlement in Northern Iceland: historical ecology of human impact and climate fluctuation on the millennial scale. American Anthropologist 109: 27-51.

Jóhannesson H, Einarsson S (1988) Krísuvíkureldar I. Aldur Ögmundarhrauns og Miðaldalagsins. Jökull 38: 71-87.

Óladóttir BA, Larsen G and Sigmarsson O. (2011) Holocene volcanic activity at Grímsvötn, Bárdarbunga and Kverkfjöll subglacial centres beneath Vatnajökull, Iceland. Bulletin of Volcanology 73: 1187-1208.

Ólafsdóttir R and Gudmundsson HJ (2002) Holocene land degradation and climatic change in northeastern Iceland. The Holocene 12: 159-167.

R Core Team (2013) R: A language and environment for statistical computing. Vienna: R Foundation for Statistical Computing. URL http://www.R-project.org/.

Reimer PJ, Baillie MGL, Bard E, et al. (2009) INTCAL09 And Marine09 Radiocarbon Age Calibration Curves, 0-50,000 Years Cal BP. Radiocarbon 51: 1111-1150.

Reimer PJ, Bard E, Bayliss A, et al. (2013) INTCAL13 and Marine13 Radiocarbon Age Calibration Curves 0-50,000 Years Cal BP. Radiocarbon 55: 1869-1887.

Rick TC, Kirch PV, Erlandson JM and Fitzpatrick SM (2013) Archaeology, deep history, and the human transformation of island ecosystems. Anthropocene 4: 33-45. 
Róbertsdóttir BG, (1992) Gjóskulagatímatal fyrir Suðurlandsundirlendi. Prjú forsöguleg gjóskulög frá Heklu, HA, HB og HC. Veggspjaldaráðstefna Jarðfræðafélags

Íslands. Jarðfræðafélag Î́slands, Reykjavík, pp. 6-7

Róbertsdóttir BG, Larsen G and Eiríksson J (2002) A new detailed stratigraphical and geochemical record of 30 tephra layers from the Hekla volcanic system, Iceland, 2980850 cal. yr BP. The 25th Nordic Geological Winter Meeting, Abstracts volume, 178. Reykjavík.

Ruddiman W (2003) The anthropogenic greenhouse era began thousands of years ago. Climatic Change 61: 261-293.

Ruddiman WF, Ellis EC, Kaplan JO, et al. (2015) Defining the epoch we live in. Science 348: 38-39.

Sæmundsson K (1991) Jardfrædi Kröflukerfisins (Geology of the Krafla volcanic system) In: Gardarson A, Einarsson Á (Eds.) Náttúra Myvatns. Hid íslenska náttúrufrædifeélag, Reykjavík, p. 25-95.

Sigurmundsson F, Gísladóttir G and Óskarsson H (2014) Decline of birch woodland cover in Pjórsárdalur Iceland from 1587 to 1938. Human Ecology 42: 577-590.

Smith BD and Zeder MA (2013) The onset of the Anthropocene. Anthropocene 4: 8-13.

Steffen W, Broadgate W, Deutsch L, et al. (2015) The trajectory of the Anthropocene: The Great Acceleration. The Anthropocene Review 2: 81-98.

Streeter R. (2011) Tephrochonology, landscape and population: impacts of plague on medieval Iceland. Unpublished PhD thesis: University of Edinburgh. 
Streeter R and Dugmore AJ (2014) Late-Holocene land surface change in a coupled social-ecological system, southern Iceland: a cross-scale tephrochronology approach. Quaternary Science Reviews 86: 99-114.

Streeter R, Dugmore AJ and Vesteinsson O (2012) Plague and landscape resilience in premodern Iceland. Proceedings of the National Academy of Sciences of the United States of America 109: 3664-3669.

Stuiver M, Reimer PJ, Bard E, Beck JW, Burr GS, Hughen KA, McCormac FG, Plicht JVD, Spurk M (1998) INTCAL98 Radio- carbon age calibration 24, 000-0 BP. Radiocarbon $40: 1041-1083$

Thórarinsson S, (1944) Tefrokronoliska studier pa Island (Tephrochronological studies in Iceland). Geografiska Annaler, 26, 1-217.

Thórarinsson S, (1952) Hverfjall I. Náttúrufrædingurinn 22, 113-129

Thórarinsson S (1955) Nákuðungslögin við Húnaflóa í ljósli nýrra aldursákvarðana. Náttúrufræðingurinn 25: 172-186.

Thórarinsson S (1958) The Öræfajökull eruption of 1362. Vol. II. Acta Naturalia islandica.

Thórarinsson S, (1961) Uppblástur á Island í ljósi öskulagarannsókna (Wind erosion in Iceland. A tephrochronological study). Ársrit Skó græktarfëlags Islands, 17-54.

Thórarinsson S (1967) The Eruptions of Hekla in historical times. The Eruption of Hekla 1947-1948. 1: 1-170

Thórarinsson S (1971) Aldur ljósu gjóskulaganna úr Heklu samkvæmt leiðréttu geislakolstímatali. Náttúrufræðingurinn 41:99-105

Thórarinsson. S (1975) Katla og annáll Kötlugosa. Árbók Ferðafélags Íslands. 
Vésteinsson 0, Porláksson H, Einarsson Á (2006) Reykjavík 871ェ2. Landnámssýningin.

The settlement exhibition. Reykjavík: Reykjavík City Museum, 144 pp.

Vésteinsson 0 and McGovern TH (2012) The Peopling of Iceland. Norwegian Archaeological Review 45: 206-218.

Vickers K, Erlendsson E, Church MJ, Edwards KJ and Bending J (2011) 1000 years of environmental change and human impact at Stora-Mork, southern Iceland: a multiproxy study of a dynamic and vulnerable landscape. The Holocene 21: 979-995.

Vinther BM, Clausen HB, Johnsen SJ, Rasmussen SO, Anderson KK, Buchardt SL, DahlJensen D, Seierstad IK, Siggaard-Andereson JP, Steffensen JP, Svensson A, Olsen O, Heinemeier J (2006) A synchronized dating of three Greenland ice cores throughout the Holocene. Journal of Geophysical Research 111 :1-11.

Yates J. (1994) Volcanoes, climate sheep and people: the story of a changing landscape in Iceland. MSc dissertation, Environmental Archaeology and Palaeoeconomy, University of Sheffield.

Zalasiewicz J, Williams M, Steffen W, Crutzen P (2010) The New World of the Anthropocene. Environmental Science \& Technology 44: 2228-2231.

Zalasiewicz J, Williams M, Fortey R, Smith A, Barry TL, Coe AL, Bown PR, Rawson PF, Gale A, Gibbard P, Gregory FJ, Hounslow MW, Kerr AC, Pearson P, Knox R, Powell J, Waters C, Marshall J, Oates M and Stone P (2011) Stratigraphy of the Anthropocene. Philosophical Transactions of the Royal Society A369: 1036-1055.

Zalasiewicz, J, Waters CN, Williams M, Barnosky AD, Cearreta A, Crutzen P, Ellis E, Ellis MA, Fairchild IJ, Grinevald J, Haff PK, Hajdas I, Leinfelder R, McNeill J, Odada EO, Poirier 
C, Richter D, Steffen W, Summerhayes C, Syvitski JPM, Vidas D, Wagreich M, Wing SL, Wolfe AP, An Z, Oreskes N (in press) When did the Anthropocene begin? A midtwentieth century boundary level is stratigraphically optimal. Quaternary International.

Zori D, Byock J, Erlendsson E, Martin S, Wake T and Edwards KJ (2013) Feasting in Viking Age Iceland: sustaining a chiefly political economy in a marginal environment. Antiquity 87: 150-165.

Zielinski GA, Mayewski PA, Meeker LD, Grönvold, K, Germani MS, Whitlow S, Twickler MS, Taylor K (1997) Volcanic aerosol records and tephrochronology of the Summit, Greenland, ice cores. Journal of Geophysical Research-Oceans 102: 26625-26640. 
Table 1

\begin{tabular}{|c|c|c|c|}
\hline Site & $\begin{array}{l}\text { Latitude } \\
\left({ }^{\circ} \mathrm{N}\right)\end{array}$ & $\begin{array}{l}\text { Longitude } \\
\left({ }^{\circ} \mathrm{E}\right)\end{array}$ & Reference \\
\hline Arnarvatn & 65.61 & -17.24 & Brown et al. (2012) \\
\hline Engimýyri & 63.50 & -18.88 & A.J. Newton, unpub. \\
\hline Fjall 2 & 63.49 & -19.23 & Yates (1994) \\
\hline Fjall 12 & 63.49 & -19.23 & Yates (1994) \\
\hline Hofstaðir & 65.61 & -17.16 & Lucas et al. (2009) \\
\hline HörgardalurHörgárdalur & 65.66 & -18.49 & $\begin{array}{l}\text { R. Streeter and A.J. Dugmore, } \\
\text { unpub. }\end{array}$ \\
\hline Kirfandi Fan & 63.49 & -19.25 & Dugmore (1987) \\
\hline Kotagil & 63.64 & -19.94 & Dugmore (1987) \\
\hline Núpsstaðarskógar & 64.06 & -17.46 & ÓladóttirOladottir et al. (2011) \\
\hline Reykjanes K4 & 63.86 & -22.10 & Gísladóttir et al. (2010) \\
\hline Reykjanes K6 & 63.87 & -22.06 & Gísladóttir et al. (2010) \\
\hline Reykjanes K7 & 63.86 & -22.05 & Gísladóttir et al. (2010) \\
\hline Sandfell & 65.52 & -17.20 & Brown et al. (2012) \\
\hline Seljaland & 63.62 & -19.98 & Dugmore (1987) \\
\hline
\end{tabular}




\begin{tabular}{|c|c|c|c|}
\hline Skaftar 147 & 63.66 & -18.53 & Streeter (2011) \\
\hline Skaftar 150 & 63.65 & -18.54 & Streeter (2011) \\
\hline Skaftar 155 & 63.66 & -18.52 & Streeter (2011) \\
\hline Skaftar 157 & 63.83 & -18.59 & Streeter (2011) \\
\hline Skaftar 169 & 63.88 & -18.59 & Streeter (2011) \\
\hline Skaftar 171 & 63.79 & -18.53 & Streeter (2011) \\
\hline Skaftar 172 & 63.79 & -18.53 & Streeter (2011) \\
\hline Skaftar 174 & 63.87 & -18.59 & Streeter (2011) \\
\hline Skaftar 175 & 63.88 & -18.59 & Streeter (2011) \\
\hline Skaftar 178 & 63.88 & -18.59 & Streeter (2011) \\
\hline Skaftar 182 & 63.80 & -18.53 & Streeter (2011) \\
\hline Skaftar 184 & 63.80 & -18.54 & Streeter (2011) \\
\hline Steinadalur & 64.16 & -16.00 & ÓladóttirOladottir et al. (2011) \\
\hline Svalbarð & 66.36 & -15.85 & $\begin{array}{l}\text { A.J. Dugmore and A.J. Casely, } \\
\text { unpub. }\end{array}$ \\
\hline Svínavatn 1 & 65.51 & -19.96 & Boygle (1999) \\
\hline Svínavatn 6 & 65.50 & -20.08 & Boygle (1999) \\
\hline Svínavatn 8 & 65.50 & -20.38 & Boygle (1999) \\
\hline
\end{tabular}




\begin{tabular}{|l|l|l|l|}
\hline Svínavatn 10 & 65.51 & -19.95 & Boygle (1999) \\
\hline Svínavatn 11 & 65.55 & -20.16 & Boygle (1999) \\
\hline bjórsá & 64.09 & -19.95 & Thórarinsson (1960) \\
\hline Vatnagarðar & 64.00 & -19.97 & Thórarinsson (1960) \\
\hline Ytri-Skógar & 63.53 & -19.52 & Dugmore (1987) \\
\hline
\end{tabular}

Table 2

\begin{tabular}{|l|l|l|l|l|}
\hline Site & Latitude $\left.\mathbf{~}^{\circ} \mathbf{N}\right)$ & Longitude $\left({ }^{\circ} \mathbf{E}\right)$ & Reference & Type \\
\hline Borgarmýri 1 & 64.10 & -21.72 & $\begin{array}{l}\text { Einarsson (1961, } \\
1963 a)\end{array}$ & Mire \\
\hline Borgarmýri 2 & 64.10 & -21.72 & $\begin{array}{l}\text { Einarsson (1961, } \\
1963 a)\end{array}$ & Mire \\
\hline Breiðavatn & 64.68 & -21.25 & $\begin{array}{l}\text { Gathorne-Hardy et } \\
\text { al. (2009) }\end{array}$ & Lake \\
\hline Hallormsstaður & 65.10 & -14.74 & Einarsson (1961) & Mire \\
\hline Helgutjörn & 65.09 & -14.72 & $\begin{array}{l}\text { Jónsson et al. } \\
(2012)\end{array}$ & Lake \\
\hline Helluvaðstjörn & 65.58 & -17.18 & $\begin{array}{l}\text { Lawson et al. } \\
(2007)\end{array}$ & Lake \\
\hline Hestvatn & 64.01 & -20.71 & Hallsdóttir (1995) & Lake \\
\hline
\end{tabular}




\begin{tabular}{|c|c|c|c|c|}
\hline Hrísheimar HR6 & 65.52 & -17.10 & Lawson (2009) & Mire \\
\hline Krosshóll & 65.78 & -18.62 & $\begin{array}{l}\text { Caseldine \& and } \\
\text { Hatton (1994) }\end{array}$ & Mire \\
\hline Moldhaugar X & 65.74 & -18.20 & $\begin{array}{l}\text { Einarsson (1961, } \\
\text { 1963b) }\end{array}$ & Mire \\
\hline Moldhaugar XI & 65.74 & -18.20 & $\begin{array}{l}\text { Einarsson (1961, } \\
\text { 1963b) }\end{array}$ & Mire \\
\hline Naustamýri & 65.66 & -18.09 & $\begin{array}{l}\text { Thórarinsson } \\
\text { (1955) }\end{array}$ & Mire \\
\hline Ölfus & 63.97 & -21.09 & $\begin{array}{l}\text { Einarsson (1957a, } \\
\text { 1961) }\end{array}$ & Mire \\
\hline $\begin{array}{l}\text { Reykjarfjörður B997 } \\
\text { 328PC }\end{array}$ & 65.96 & -21.55 & $\begin{array}{l}\text { Andrews et al. } \\
(2001)\end{array}$ & Marine \\
\hline Reykjanes K6 & 63.87 & -22.06 & $\begin{array}{l}\text { Gísladóttir et al. } \\
\text { (2010) }\end{array}$ & Mire \\
\hline Skálholt & 64.13 & -20.53 & $\begin{array}{l}\text { Einarsson (1963a, } \\
\text { b) }\end{array}$ & Mire \\
\hline Sogamýri & 64.14 & -21.89 & $\begin{array}{l}\text { Einarsson (1957a, } \\
\text { b, 1961, 1963b) }\end{array}$ & Mire \\
\hline Sólheimagerði & 65.48 & -19.27 & Einarsson (1961) & Mire \\
\hline Svínavatn & 64.10 & -20.69 & Hallsdóttir (1987) & Lake \\
\hline Prándarholt & 64.04 & -20.36 & Hallsdóttir (1987) & Mire \\
\hline Torfalækur & 65.59 & -20.31 & Einarsson (1961) & Mire \\
\hline Varmahlíð & 65.57 & -19.37 & Einarsson (1961) & Mire \\
\hline
\end{tabular}




\begin{tabular}{|l|l|l|l|l|}
\hline Vatnskotsvatn & 65.70 & -19.48 & Hallsdóttir (1995) & Lake \\
\hline $\begin{array}{l}\text { Vestra- } \\
\text { _Gíslholtsvatn }\end{array}$ & 63.94 & -20.52 & $\begin{array}{l}\text { Hallsdóttir \& and } \\
\text { Caseldine (2005) }\end{array}$ & Lake \\
\hline Ytri-_Bægisá & 65.67 & -18.40 & Bartley (1973) & Mire \\
\hline
\end{tabular}

Table 3

\begin{tabular}{|c|c|c|c|c|c|}
\hline Name & $\begin{array}{l}\text { Volcanic } \\
\text { system }\end{array}$ & ${ }^{14} \mathrm{C}$ date & $\begin{array}{l}\text { Calibrated } \\
\text { date (cal yr) }\end{array}$ & $\begin{array}{l}\text { Calibration } \\
\text { curve }\end{array}$ & Reference \\
\hline Katla 1918 & Katla & $\begin{array}{l}- \\
\text { (Historic) }\end{array}$ & 1918 AD & - & $\begin{array}{l}\text { Thórarinsson } \\
\text { (1975) }\end{array}$ \\
\hline Askja 1875 & Askja & (Historic) & $1875 \mathrm{AD}$ & - & $\begin{array}{l}\text { Thórarinsson } \\
\text { (1944) }\end{array}$ \\
\hline Hekla 1845 & Hekla & (Historic) & $1845 \mathrm{AD}$ & - & $\begin{array}{l}\text { Thórarinsson } \\
\text { (1967) }\end{array}$ \\
\hline Katla 1823 & Katla & (Historic) & 1823 AD & - & $\begin{array}{l}\text { Thórarinsson } \\
\text { (1975) }\end{array}$ \\
\hline
\end{tabular}




\begin{tabular}{|c|c|c|c|c|c|}
\hline $\begin{array}{l}\text { Laki- } \\
\text { Grímsvötn } \\
1783\end{array}$ & $\begin{array}{l}\text { Laki- } \\
\text { Grímsvötn }\end{array}$ & - & $1783 \mathrm{AD}$ & - & $\begin{array}{l}\text { Thórarinsson } \\
\text { (1967) }\end{array}$ \\
\hline Katla 1755 & Katla & (Historic) & $1755 \mathrm{AD}$ & - & $\begin{array}{l}\text { Thórarinsson } \\
\text { (1975) }\end{array}$ \\
\hline Hekla 1693 & Hekla & (Historic) & $1693 \mathrm{AD}$ & - & $\begin{array}{l}\text { Thórarinsson } \\
\text { (1967) }\end{array}$ \\
\hline Katla 1660 & Katla & (Historic) & $1660 \mathrm{AD}$ & - & $\begin{array}{l}\text { Thórarinsson } \\
\text { (1975) }\end{array}$ \\
\hline Katla 1625 & Katla & (Historic) & $1625 \mathrm{AD}$ & - & $\begin{array}{l}\text { Thórarinsson } \\
\text { (1975) }\end{array}$ \\
\hline Katla 1612 & Katla & (Historic) & $1612 \mathrm{AD}$ & - & $\begin{array}{l}\text { Thórarinsson } \\
\text { (1975) }\end{array}$ \\
\hline Hekla 1597 & Hekla & (Historic) & $1597 \mathrm{AD}$ & - & $\begin{array}{l}\text { Thórarinsson } \\
\text { (1967) }\end{array}$ \\
\hline Katla 1500 & Katla & (Historic) & $1500 \mathrm{AD}$ & - & $\begin{array}{l}\text { Larsen (1984, } \\
\text { 2); Larsen } \\
\text { (2000) }\end{array}$ \\
\hline
\end{tabular}




\begin{tabular}{|c|c|c|c|c|c|}
\hline $\begin{array}{l}\text { Veðivötn } \\
1477\end{array}$ & Veðivötn & (Historic) & $1477 \mathrm{AD}$ & - & $\begin{array}{l}\text { Larsen } \\
\text { (1984) }\end{array}$ \\
\hline $\begin{array}{l}\text { Grímsvötn } \\
1457 \pm 5\end{array}$ & Grímsvötn & $\begin{array}{l}- \\
\text { (Sedimen } \\
t \\
\text { accumula } \\
\text { tion) }\end{array}$ & $1457 \pm 5 \mathrm{AD}$ & - & $\begin{array}{l}\text { Streeter and } \\
\text { Dugmore } \\
\text { (2014); } \\
\sim 1460 \mathrm{AD} \\
\text { Óladóttir et } \\
\text { al., (2011) }\end{array}$ \\
\hline $\begin{array}{l}\text { Grímsvötn } \\
1432 \pm 5\end{array}$ & Grímsvötn & $\begin{array}{l}- \\
\text { (Sedimen } \\
t \\
\text { accumula } \\
\text { tion) }\end{array}$ & $1432 \pm 5 \mathrm{AD}$ & - & $\begin{array}{l}\text { Streeter and } \\
\text { Dugmore } \\
\text { (2014);, AD } \\
\sim 1430 \\
\text { Óladóttir et } \\
\text { al., (2011) }\end{array}$ \\
\hline Katla 1416 & Katla & (Historic) & $1416 \mathrm{AD}$ & - & $\begin{array}{l}\text { Larsen } \\
(2000)\end{array}$ \\
\hline Katla 1357 & Katla & (Historic) & $1357 \mathrm{AD}$ & - & $\begin{array}{l}\text { Larsen and } \\
\text { Thorarinsson } \\
\text { Thórarinsson } \\
\text { (1984) }\end{array}$ \\
\hline
\end{tabular}




\begin{tabular}{|c|c|c|c|c|c|}
\hline Hekla 1389 & Hekla & (Historic) & 1389 AD & - & $\begin{array}{l}\text { Thórarinsson } \\
\text { (1967) }\end{array}$ \\
\hline $\begin{array}{l}\text { Öræfajökull } \\
1362\end{array}$ & $\begin{array}{l}\text { Öræfajökul } \\
l\end{array}$ & (Historic) & $1362 \mathrm{AD}$ & - & $\begin{array}{l}\text { Thórarinsson } \\
\text { (1958) }\end{array}$ \\
\hline Hekla 1341 & Hekla & (Historic) & $1341 \mathrm{AD}$ & - & $\begin{array}{l}\text { Thórarinsson } \\
\text { (1967) }\end{array}$ \\
\hline Hekla 1300 & Hekla & (Historic) & $1300 \mathrm{AD}$ & - & $\begin{array}{l}\text { Thórarinsson } \\
\text { (1967) }\end{array}$ \\
\hline Katla 1262 & Katla & (Historic) & $1262 \mathrm{AD}$ & - & $\begin{array}{l}\text { Thórarinsson, } \\
\text { (1975); } \\
\text { Larsen } \\
\text { (2000) }\end{array}$ \\
\hline R_1226 & Reykjanes & (Historic) & $1226 \mathrm{AD}$ & - & $\begin{array}{l}\text { Jóhannesson } \\
\text { and } \\
\text { Einarsson, } \\
\text { (1988) }\end{array}$ \\
\hline Hekla 1206 & Hekla & (Historic) & 1206 AD & - & $\begin{array}{l}\text { Thórarinsson } \\
\text { (1967) }\end{array}$ \\
\hline
\end{tabular}




\begin{tabular}{|c|c|c|c|c|c|}
\hline $\begin{array}{l}\text { T } 1151 \\
\text { (scoria } \\
\text { layer) }\end{array}$ & $\begin{array}{l}\text { Trölladyng } \\
\text { ja }\end{array}$ & (Historic) & $1151 \mathrm{AD}$ & - & $\begin{array}{l}\text { Jóhannesson } \\
\text { and Einarsson } \\
\text { (1988) }\end{array}$ \\
\hline Hekla 1104 & Hekla & (Historic) & 1104 AD & - & $\begin{array}{l}\text { Thórarinsson } \\
\text { (1967) }\end{array}$ \\
\hline $\begin{array}{l}\text { Eldgjá } \\
\text { (E935) }\end{array}$ & Katla & $\begin{array}{l}\text { - (Ice } \\
\text { core) }\end{array}$ & $\begin{array}{l}\text { 934-938 AD, } \\
933 \pm 1 \text { (in } \\
\text { Greenland ice } \\
\text { core) }\end{array}$ & - & $\begin{array}{l}\text { Larsen } \\
(2000) ; \\
\text { Vinther et al., } \\
(2006)\end{array}$ \\
\hline Katla 920 & Katla & $\begin{array}{l}- \\
\text { (Sedimen } \\
\mathrm{t} \\
\text { accumula } \\
\text { tion) }\end{array}$ & & - & $\begin{array}{l}\text { Haflijason et } \\
\text { al., (1992) }\end{array}$ \\
\hline $\begin{array}{l}\text { AD } 915 \pm 15 \\
\text { (Helgutjörn) }\end{array}$ & $\begin{array}{l}\text { VeiðivötnU } \\
\text { nknown }\end{array}$ & $\begin{array}{l}\text { (Sedimen } \\
\text { t } \\
\text { accumula } \\
\text { tion) }\end{array}$ & & - & $\begin{array}{l}\text { Larsen } \\
\text { (1982); } \\
\text { Jónsson } \\
\text { (2009) } \\
\text { Jónsson et al. } \\
\text { (2012) }\end{array}$ \\
\hline
\end{tabular}




\begin{tabular}{|c|c|c|c|c|c|}
\hline Landnám & $\begin{array}{l}\text { Vatnaöldur } \\
\text { /Torfajöku } \\
\text { ll }\end{array}$ & $\begin{array}{l}\text { - (Ice } \\
\text { Core) }\end{array}$ & $\begin{array}{l}871 \pm 2 \mathrm{AD} \\
877 \pm 4 \mathrm{AD}\end{array}$ & - & $\begin{array}{l}\text { Grönvold et } \\
\text { al. (1995); } \\
\text { Zielinski et al. } \\
\text { (1997) }\end{array}$ \\
\hline $\begin{array}{l}\text { AD } \\
\text { 700Hrafnkat } \\
\text { la c. AD } 700 \\
\text { (Helgutjörn) }\end{array}$ & $\begin{array}{l}\text { UnknownK } \\
\text { atla }\end{array}$ & $\begin{array}{l}- \\
\text { (Sedimen } \\
\mathrm{t} \\
\text { accumula } \\
\text { tion) }\end{array}$ & & - & $\begin{array}{l}\text { Jónsson } \\
\text { (2009); } \\
\text { Jónsson et al. } \\
\text { (2012) }\end{array}$ \\
\hline Еy H (E500) & $\begin{array}{l}\text { Eyjafjallajö } \\
\text { kull }\end{array}$ & $\begin{array}{l}1540 \pm 5 \\
0 \mathrm{BP}\end{array}$ & $520 \mathrm{AD}$ & $\begin{array}{l}\text { Reimer et al. } \\
\text { (2009) }\end{array}$ & $\begin{array}{l}\text { Dugmore et } \\
\text { al. (2013) }\end{array}$ \\
\hline SILK-YN & Katla & $\begin{array}{l}1676 \pm 12 \\
\text { BP }\end{array}$ & $371 \mathrm{AD}$ & $\begin{array}{l}\text { Reimer et al. } \\
\text { (2013) }\end{array}$ & $\begin{array}{l}\text { Larsen et al. } \\
\text { (2001) }\end{array}$ \\
\hline $\begin{array}{l}\text { Grákolla and } \\
\text { Askja }\end{array}$ & $\begin{array}{l}\text { Torfajokull } \\
\text { Torfajökull } \\
\text { and Askja }\end{array}$ & $\begin{array}{l}1995 \pm 30 \\
\mathrm{BP}\end{array}$ & $10 \mathrm{AD}$ & $\begin{array}{l}\text { Stuiver et al. } \\
\text { (1998) }\end{array}$ & $\begin{array}{l}\text { Óladóttir et al. } \\
\text { (2011) }\end{array}$ \\
\hline Layer L & Katla & $\begin{array}{l}2260 \pm 60 \\
\text { BP }\end{array}$ & $290 \mathrm{BC}$ & $\begin{array}{l}\text { Reimer et al. } \\
\text { (2013) }\end{array}$ & $\begin{array}{l}\text { Dugmore et } \\
\text { al. (1987) }\end{array}$ \\
\hline Hverfjall & Hverfjall & $2500 \mathrm{BP}$ & & - Not & $\begin{array}{l}\text { Thórarinsson } \\
\text { (1952); }\end{array}$ \\
\hline
\end{tabular}




\begin{tabular}{|c|c|c|c|c|c|}
\hline & & & & specified & $\begin{array}{l}\text { Sæaemundss } \\
\text { on (1991) }\end{array}$ \\
\hline Hekla-A & Hekla & $\begin{array}{l}\text { - Not } \\
\text { specified }\end{array}$ & $590 \mathrm{BC}$ & $\begin{array}{l}\text { - Not } \\
\text { specified }\end{array}$ & $\begin{array}{l}\text { Robertsdóttir } \\
\text { Róbertsdóttir } \\
\text { (19922002b); } \\
\text { Erlendsson } \\
\text { (2007) }\end{array}$ \\
\hline SILK-UN & Katla & $\begin{array}{l}2660 \pm 12 \\
\text { BP }\end{array}$ & 845 BC & $\begin{array}{l}\text { Stuiver et al. } \\
\text { (1998) }\end{array}$ & $\begin{array}{l}\text { Larsen et al. } \\
\text { (2001) }\end{array}$ \\
\hline Katla E & Katla & $\begin{array}{l}\text { (Sedimen } \\
\mathrm{t} \\
\text { accumula } \\
\text { tion) }\end{array}$ & $1000 \mathrm{BC}$ & - & $\begin{array}{l}\text { Robertsdóttir } \\
\text { (1992b); } \\
\text { Erlendsson } \\
\text { (2007) }\end{array}$ \\
\hline Hekla-3 & Hekla & $\begin{array}{l}2879 \pm 34 \\
\text { BP }\end{array}$ & $1050 \mathrm{BC}$ & $\begin{array}{l}\text { Stuiver et al. } \\
\text { (1998) }\end{array}$ & $\begin{array}{l}\text { Dugmore et } \\
\text { al., (1995) }\end{array}$ \\
\hline SILK-MN & Katla & $\begin{array}{l}2975 \pm 12 \\
\text { BР }\end{array}$ & $1212 \mathrm{BC}$ & $\begin{array}{l}\text { Reimer et al. } \\
\text { (2013) }\end{array}$ & $\begin{array}{l}\text { Larsen et al. } \\
\text { (2001) }\end{array}$ \\
\hline SILK-LN & Katla & $\begin{array}{l}3139 \pm 40 \\
\text { BP }\end{array}$ & $1430 \mathrm{BC}$ & $\begin{array}{l}\text { Stuiver et al. } \\
\text { (1998) }\end{array}$ & $\begin{array}{l}\text { Larsen et al. } \\
\text { (2001) }\end{array}$ \\
\hline
\end{tabular}




\begin{tabular}{|c|c|c|c|c|c|}
\hline Katla N & Katla & $\begin{array}{l}- \\
\text { (Sedimen } \\
t \\
\text { accumula } \\
\text { tion) }\end{array}$ & $1590 \mathrm{BC}$ & - & $\begin{array}{l}\text { Robertsdóttir } \\
\text { Róbertsdóttir } \\
\text { (1992b); } \\
\text { Erlendsson } \\
\text { (2007) }\end{array}$ \\
\hline Layer K & Katla & $\begin{array}{l}3480 \pm 60 \\
\text { BP }\end{array}$ & 1813 BC & $\begin{array}{l}\text { Reimer et al. } \\
\text { (2013) }\end{array}$ & $\begin{array}{l}\text { Dugmore et } \\
\text { al. (1987) }\end{array}$ \\
\hline HS & Hekla & $\begin{array}{l}3515 \pm 55 \\
\text { ВР }\end{array}$ & 1855 BC & $\begin{array}{l}\text { Stuiver et al. } \\
\text { (1998) }\end{array}$ & $\begin{array}{l}\text { Larsen et al. } \\
\text { (2001) }\end{array}$ \\
\hline Hekla-4 & Hekla & $\begin{array}{l}3826 \pm 12 \\
\text { ВР }\end{array}$ & $2250 \mathrm{BC}$ & $\begin{array}{l}\text { Stuiver et al. } \\
\text { (1998) }\end{array}$ & $\begin{array}{l}\text { Dugmore et } \\
\text { al. (1995) }\end{array}$ \\
\hline HÖ & Hekla & $\begin{array}{l}5275 \pm 55 \\
\text { BP }\end{array}$ & $4110 \mathrm{BC}$ & $\begin{array}{l}\text { Stuiver et al. } \\
\text { (1998) }\end{array}$ & $\begin{array}{l}\text { Gudmundsdót } \\
\text { tir et al. } \\
\text { (2011) }\end{array}$ \\
\hline Hekla-5 & Hekla & $\begin{array}{l}6185 \pm 90 \\
\text { BP }\end{array}$ & $5120 \mathrm{BC}$ & $\begin{array}{l}\text { Stuiver et al. } \\
\text { (1998) }\end{array}$ & $\begin{array}{l}\text { Thórarinsson } \\
\text { (1971) }\end{array}$ \\
\hline
\end{tabular}

\section{Table 4}




\begin{tabular}{|l|l|l|l|}
\hline & Oceanic & Continental & Oceanic glaciated \\
(Iceland)
\end{tabular}




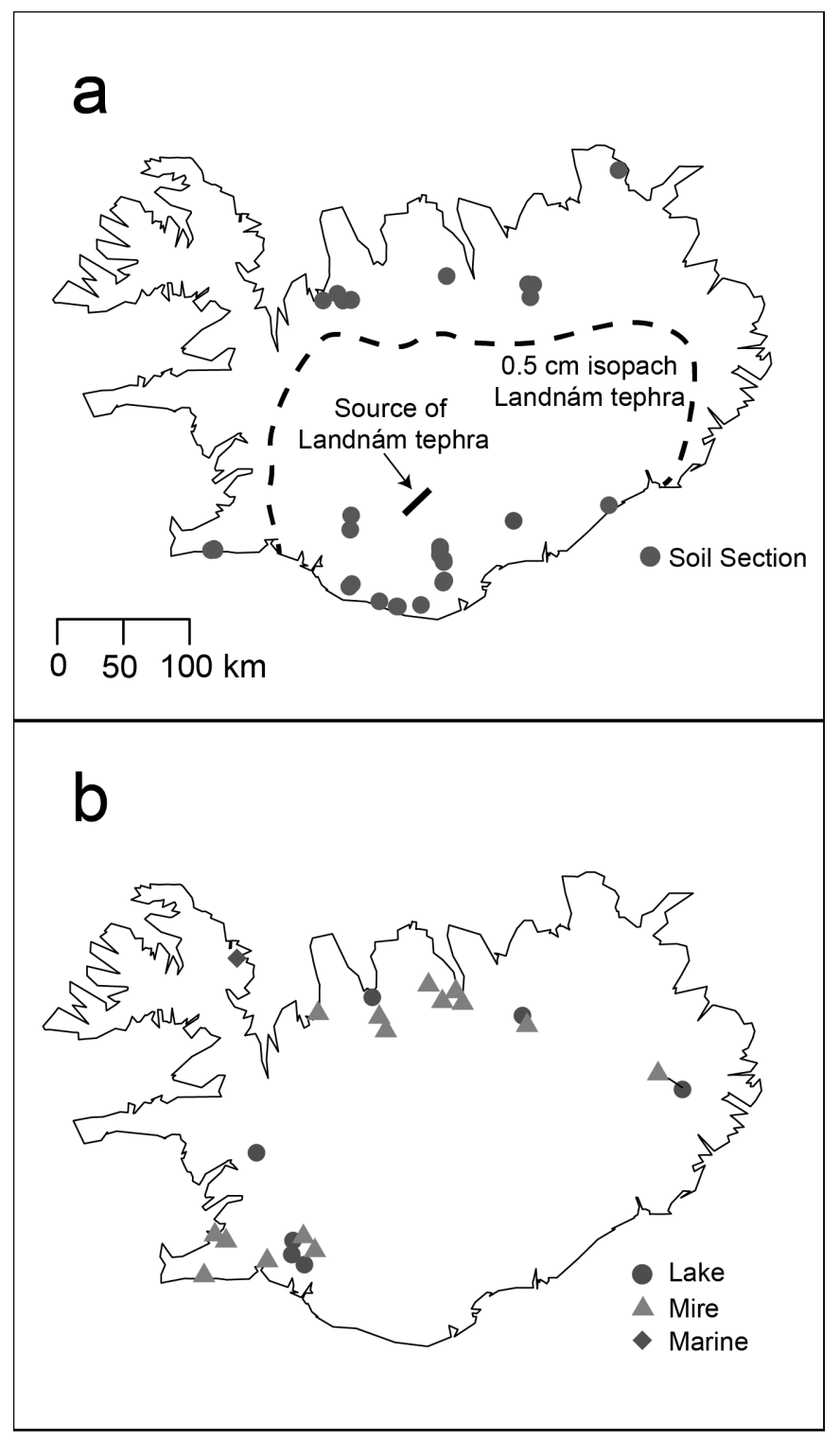


Figure 1. Locations of (a) SeAR and (b) pollen sites used in this study. The dashed line shows the $0.5 \mathrm{~cm}$ isopach of the basaltic component of the Landnám tephra layer (Larsen, 1984, 2014).

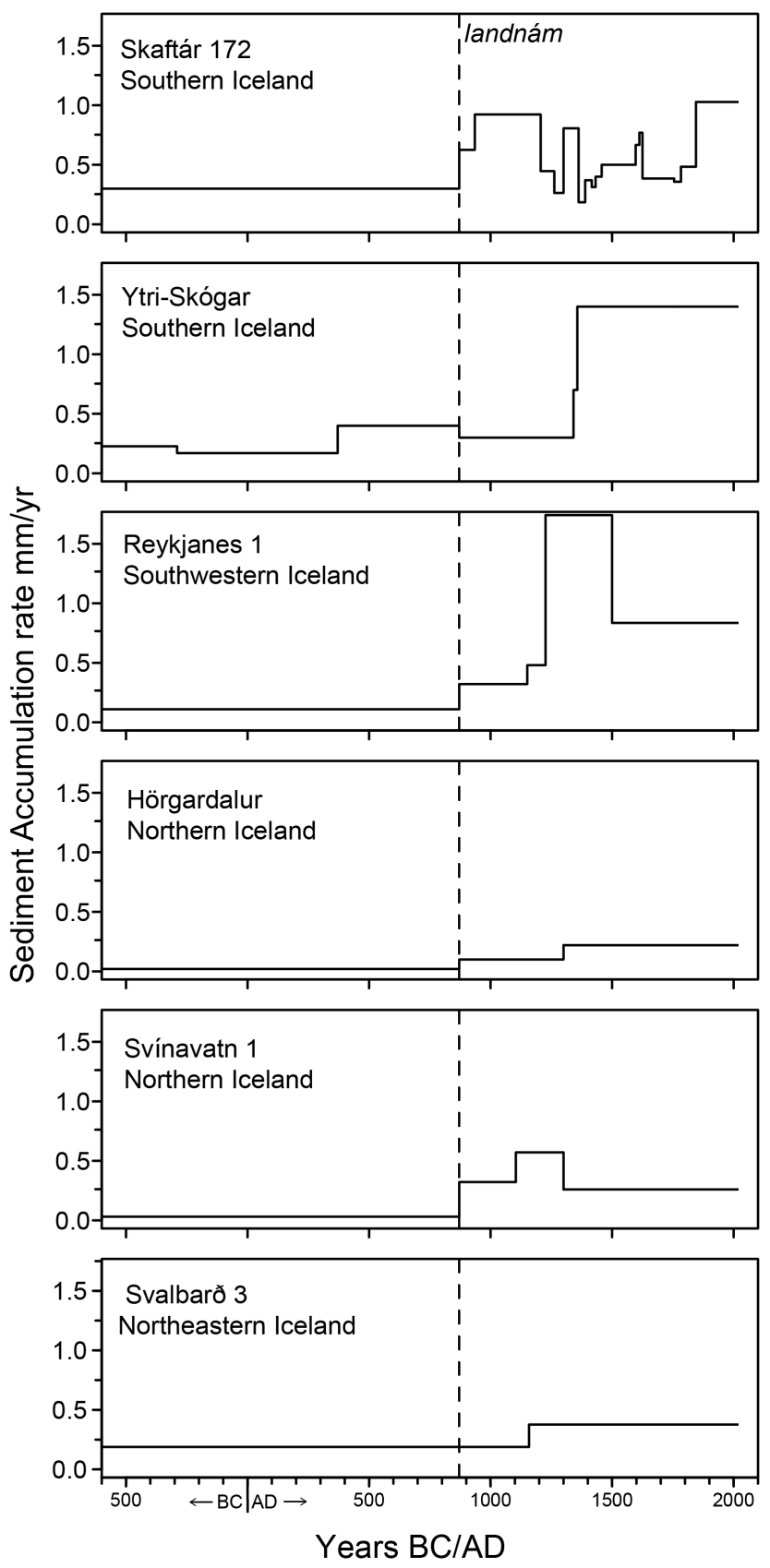


Figure 2. Examples of records of sediment accumulation rate (SeAR) as discussed in text. For sources see Table 1. Dashed line indicates landnám.

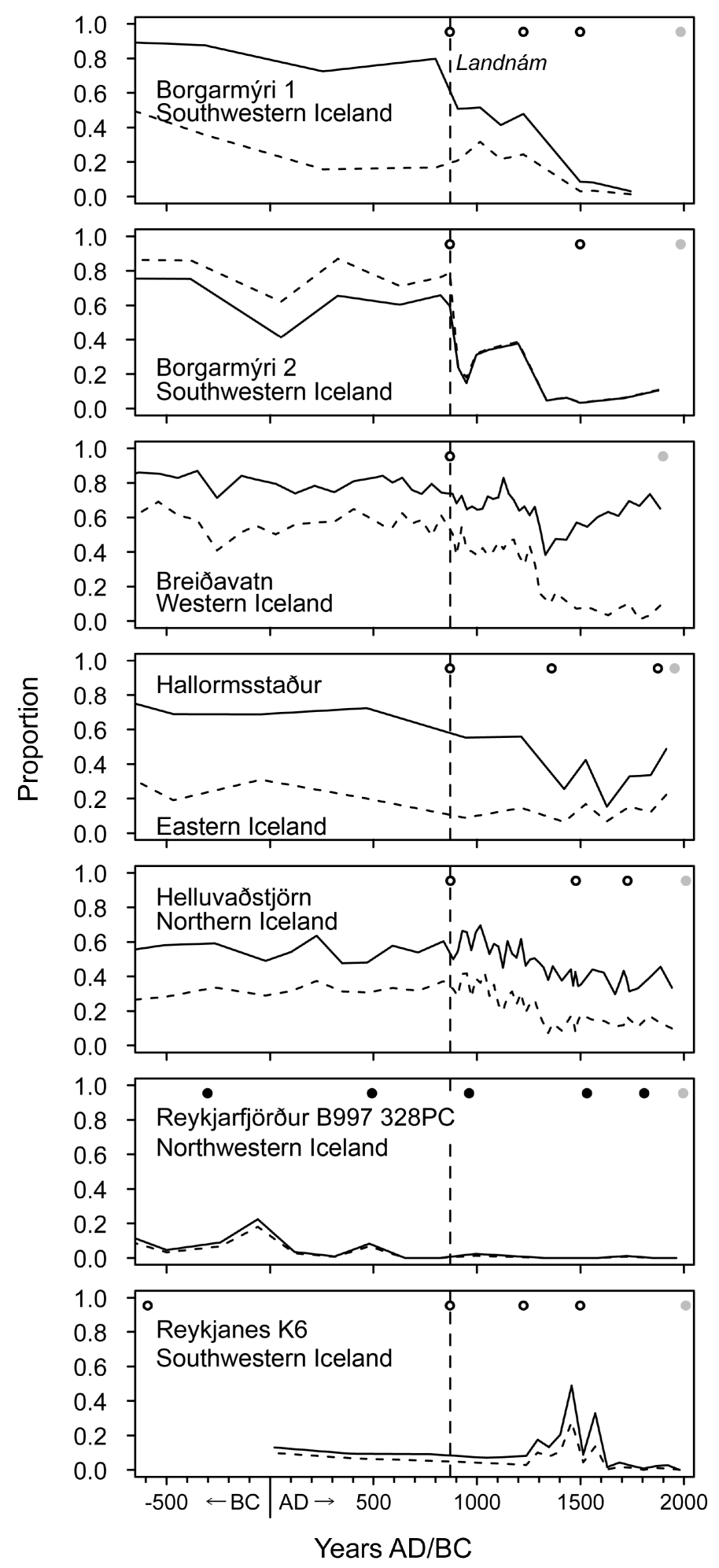


Figure 3. Examples of records of Betula pollen abundance as discussed in the text; for sources, see Table 2. Solid lines indicate the Betula proportions used in this analysis; where they vary, the Betula record shown in the original publications is indicated by a dashed line. Circles indicate age control points (grey: inferred modern surface; filled black circles: radiocarbon dates; unfilled black circles, tephra layers of known age). In all cases except Reykjanes K6, additional, older age control points lie beyond the limits of the diagram.
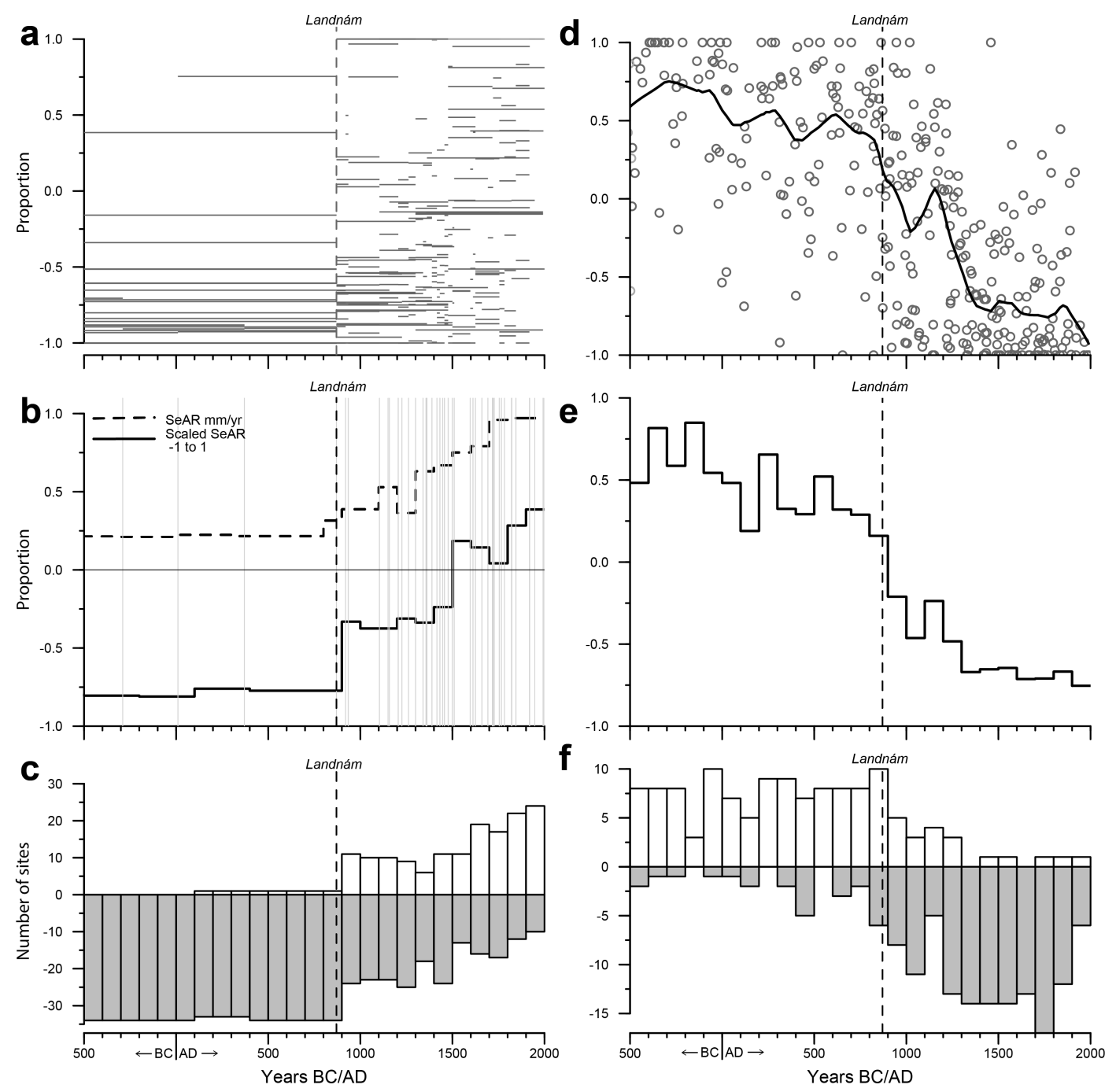

Figure 4. (a) SeAR scaled to range between -1 and 1, in order to account for betweensite differences in susceptibility to soil accumulation. Each grey horizontal line represents the mean SeAR estimated between two age control points at a given site. The 
increase in data points post landnám reflects a greater number of dated tephra layers. (b) Mean SeAR from 36 stratigraphic sections, averaged over $100 \mathrm{yr}$ windows. Grey vertical lines indicate the tephra layers used to calculate rates of accumulation. The dashed line shows absolute SeAR values and the solid line shows scaled SeAR. (c) Frequency histogram showing, for each 100-year window, the number of sites showing (for that site) above-average (white bars) or below-average (grey bars) scaled rates of sediment accumulation. (d) Betula proportions from 25 sites, calculated as described in the text. The solid line is a lowess curve through the data. (e) Betula proportions scaled to range between -1 and 1 , with the data from each site averaged in 100-year windows. (f) Frequency histograms showing, for each 100-year window, the number of sites showing (for that site) above-average (white bars) or below-average (grey bars) Betula pollen proportions.

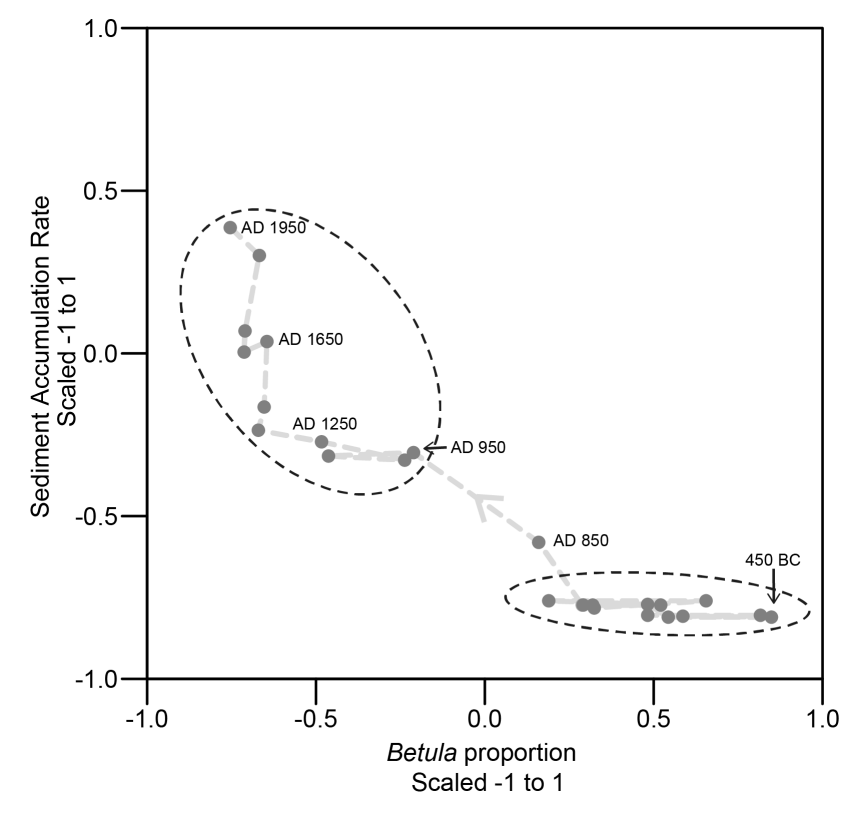

Figure 5. Biplot of Betula proportions against sediment accumulation rate (grey dots), using the 100-year averages shown in Figure. $4 \mathrm{~b}$ and $4 \mathrm{e}$. The dashed lines link temporally-adjacent dots, with the mid point of each 100-year window labelled. 


\section{Table captions}

Table 1. Records of sediment accumulation rate (SeAR) analysed in this paper.

Table 2. Pollen records analysed in this paper.

Table 3. Tephra layers used as chronostratigraphical tiepoints in this paper. The method by which the tephra layer was dated is indicated where known.

Table 4. The contrasting diversities and stabilities of islands and continents are key to understanding the local onset of the Anthropocene, and its character (developed from Cronk, 1997). Oceanic islands at low latitudes are characterised by high ultimate stability (biotal preservation), this in turn leads to high ultimate diversity (uniqueness of the biota) and low proximate diversity (species numbers) and low proximate stability (ecological vulnerabilities). Continental habitat islands contrast in every way; low uniqueness and high diversity result in greater ecological stability. High latitude islands subject to both glaciation and a narrow window of inter glacial colonization mirror continental habitat islands in all but their species diversity. As a result, anthropogenic introductions can increase biodiversity without threatening species extinction. 
